\title{
What Should Be Responsible for Eryptosis in Chronic Kidney Disease?
}

\author{
Dongxin $\mathrm{Li}^{\mathrm{a}}$ Xujuan Zheng ${ }^{\mathrm{b}}$ Yunxia Zhang ${ }^{\mathrm{a}}$ Xiangling $\mathrm{Li}^{\mathrm{a}}$ Xuexun Chen ${ }^{\mathrm{a}}$ \\ Yonghua Yin ${ }^{c}$ Jingwen $\mathrm{Hu}^{\mathrm{a}}$ Jialin $\mathrm{Li}^{\mathrm{a}} \mathrm{Min} \mathrm{Guo}^{\mathrm{a}}$ Xiangming Wang ${ }^{\mathrm{a}}$ \\ aDepartment of Nephrology, Clinical Medicine College \& Affiliated Hospital of Weifang Medical University, Weifang

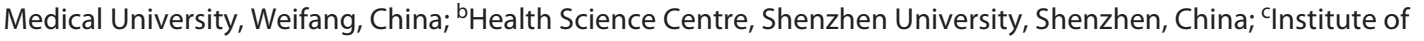 \\ Blood Transfusion, Chinese Academy of Medical Sciences \& Peking Union Medical College, Chengdu, China
}

\author{
Keywords \\ Chronic kidney disease · Anemia - Eryptosis · Oxidative \\ stress · Uremic toxin
}

\begin{abstract}
Background: Renal anemia is an important complication of chronic kidney disease (CKD). In addition to insufficient secretion of erythropoietin (EPO) and erythropoiesis disorders, the impact of eryptosis on renal anemia demands attention. However, a systemic analysis concerning the pathophysiology of eryptosis has not been expounded. Summary: The complicated conditions in CKD patients, including oxidative stress, osmotic stress, metabolic stress, accumulation of uremic toxins, and iron deficiency, affect the normal skeleton structure of red blood cells (RBCs) and disturbs ionic homeostasis, causing phosphatidylserine to translocate to the outer lobules of the RBC membrane that leads to early elimination and/or shortening of the RBC lifespan. Inadequate synthesis of RBCs cannot compensate for their accelerated destruction, thus exacerbating renal anemia. Meanwhile, EPO treatment alone will not reverse renal anemia. A variety of eryptosis inhibitors have so far been found, but evidence of their effectiveness in the treatment of CKD remains to be
\end{abstract}

established. Key Messages: In this review, the pathophysiological processes and factors influencing eryptosis in CKD were elucidated. The aim of this review was to underline the importance of eryptosis in renal anemia and determine some promising research directions or possible therapeutic targets to correct anemia in CKD.

(C) 2022 The Author(s)

Published by S. Karger AG, Basel

\section{Introduction}

Anemia, as a universal complication of chronic kidney disease (CKD), is considered to be an independent risk factor of cardiovascular events and mortality especially for patients with end-stage renal disease (ESRD) [1]. Anemia is diagnosed when hemoglobin $(\mathrm{Hb})$ falls below 13.0 $\mathrm{g} / \mathrm{dL}$ for males and $12.0 \mathrm{~g} / \mathrm{dL}$ for females. It first manifests in the early stages of CKD and gradually worsens as kidney function declines.

An epidemiological study showed that the prevalence of renal anemia was $8.4 \%, 12.2 \%, 17.4 \%, 50.3 \%$, and $53.4 \%$

Co-first authors: Dongxin Li and Xujuan Zheng.

Dongxin Li and Xujuan Zheng contributed equally to this work.

Correspondence to:

Min Guo, guomin1569@126.com

Karger@karger.com www.karger.com/kbr

2022 The Author(s).

Published by S. Karger AG, Basel

This is an Open Access article licensed under the Creative Commons Attribution-NonCommercial-4.0 International License (CC BY-NC) (http://www.karger.com/Services/OpenAccessLicense), applicable to the online version of the article only. Usage and distribution for commercial purposes requires written permission. 
in patients with CKD stages 1-5, respectively [2]. Another study revealed that anemia was diagnosed in approximately $60 \%$ of nondialysis patients and $93 \%$ of dialysis patients [3]. Without timely management, anemia will cause serious problems such as decreased quality of life, increased risk of cardiovascular events, frequent hospitalizations, and hemodialysis $[4,5]$.

In 1980s, the development of erythropoietin (EPO)stimulating agents (ESA) was a revolutionary breakthrough for the treatment of renal anemia as it not only improved the quality of life of patients with ESRD but also lessened the demand for blood [6]. To some extent, ESA can lessen the frequency of dialysis and burden of medical resources especially for CKD patients who require dialysis [7]. Follow-up studies have found that approximately $10 \%$ of patients who received ESA developed EPO resistance $[6,8]$, which is possibly related to iron deficiency and inflammation [9]. When the dose of ESA increases, the risk of cancer [10], all-cause mortality, and hospitalization would also dramatically increase $[11,12]$. In recent years, the hypoxia-inducible factor prolyl hydroxylase inhibitors, which stimulates hematopoiesis by boosting the synthesis of endogenous EPO, have been approved for clinical use [13]. However, a comprehensive data evaluation of patients with cancer is required before administration. A number of issues regarding the management of renal anemia, including defining the reasonable $\mathrm{Hb}$ level for individuals, reducing adverse effects associated with the ESA dose, and relieving the patient's financial burden need to be addressed $[14,15]$.

Insufficient EPO synthesis and iron deficiency required for red blood cell (RBC) production are the main causes of renal anemia. In addition, an investigation found that mean RBC lifespan (RBCL) in CKD stages 1-5 are $122 \pm 50,112 \pm 26,90 \pm 32,88 \pm 28$, and $60 \pm 24$ days, respectively [16]. In early CKD, the elevation of EPO levels is a response to decreased $\mathrm{Hb}$ levels partly from $\mathrm{RBC}$ destruction. New RBCs cannot immediately replenish the amount of destroyed RBCs, which may aggravate renal anemia especially in uremic patients [16-18]. For ESRD patients undergoing hemodialysis or peritoneal dialysis $[19,20]$, eryptosis cannot be disregarded due to its role in decreasing the number of circulating RBCs $[18,21,22]$. Despite its benefits, ESA use is not the only solution for renal anemia. The results of several researches that clarified the mechanisms and factors influencing eryptosis may provide promise in ameliorating renal anemia. This review narrates the pathophysiological processes of eryptosis and its main influencing factors based on current research.

\section{The Maturation Processes of Erythrocytes}

Erythrocyte maturation undergoes seven different stages of differentiation. During erythrocyte differentiation, various transmembrane proteins are synthesized or downregulated to form a spectrin-based membrane skeleton, providing stability of the membrane [23]. Ankyrin, protein 4.1, and band 3, along with spectrin and actin, collectively contribute to membrane-anchored protein cytoskeleton [24, 25]. Spectrin is mostly present during the burst-forming unit-erythroid stage, and ankyrin, band 4.1, band 3 and actin are gradually detected during the colony-forming unit-erythroid stage [26]. Regulated by EPO, the proerythroblast, which is regarded as the earliest recognizable erythrocyte, transforms into a basophilic erythroblast, polychromatic erythroblast, orthochromatic erythroblast, and reticulocyte [27-29]. During the period between the proerythroblast and orthochromatic erythroblast stages, two key changes occur: erythrocyte enucleation and change in membrane protein components. The nucleus is phagocytosed by macrophages in a way of DNase |-dependent, and the ratio changes in protein composition of the membrane were obvious. Meanwhile, three characterized changes occur. Band 3, Rh, and CD47 are highly expressed but that of CD44, ICAM-4, and $\beta 1$ integrin is markedly decreased [30]. Also, the landmark protein CD71 and XK are relatively unchanged.

During the transformation from reticulocyte to mature erythrocyte, deformability is achieved by reducing cell volume through secretory vesicles. Maturation to an adult erythrocyte is completed when reticular networks of polyribosomes are eliminated, and the biconcave shape of the plasma membrane develops [31].

Interestingly, membrane remodeling of erythrocytes proceeds individually, regardless whether the cells have completed enucleation or not [25]. During maturation, reticulocytes lose cell membrane material, content and volume, $\mathrm{Na}^{+} / \mathrm{K}^{+}$-ATPase, and $\mathrm{Na}^{+}-\mathrm{K}^{+}-2 \mathrm{Cl}^{-}$cotransport [32]. Hence, cytoskeleton changes and ion channel activity are uninterrupted throughout the process of RBC maturation.

\section{Pathophysiological Changes in Eryptosis}

Unlike apoptosis of other nucleated cells, eryptosis is erythrocyte-programmed suicide induced by exposure of phosphatidylserine (PS), which are located under the cell membrane surface. Eryptosis is characterized by membrane contraction, membrane blistering, ceramide for- 
mation, PS exposure, and macrophage phagocytosis. The special structural characteristics of RBCs determine the difference between eryptosis and other cells' apoptosis [33]. In eryptosis, the activity of some enzymes that accelerate RBC removal, such as calpain, flippase, and other proteases increases [34]. Flippase and scramblase mainly contribute to the translocation of PS; the former shifts PS from the outer leaflet to the inner leaflet, while the latter plays a reverse role. These actions have a converse effect on PS movement. Aminophospholipid transferase can affect PS translocation from the outside to the inside [35]. Externalized PS, which is an early sign of eryptosis, identifies cells for phagocytosis by macrophages. The exposed PS can then combine with Tim-1/4, stabilin-2, or CD300 located on macrophages [36]. In some cases, CD47 on RBC combine with SIRPa, preventing phagocytosis, and maintaining the $\mathrm{RBC}$ homeostasis [37].

The accumulation of ceramide is another significant characteristic of eryptosis. Ceramide can regulate the cytoskeleton and endocytosis, and it is also involved in procedures such as protein transport, subcellular localization, cell cycle, and autophagy [38]. When RBCs adopted into a hyperosmotic environment, the sphingomyelin within the RBC membrane is hydrolyzed, leading to ceramide formation [39]. Erythrocyte shrinkage then activates phospholipase A2, triggering the formation of platelet-activating factors (PAFs) [40]. Abundant amounts of PAFs induce two processes: sphingomyelin breakdown and subsequent ceramide formation [40]. Ceramide can act with $\mathrm{Ca}^{2+}$ to synergistically increase the sensitivity of $\mathrm{RBC}$ s to changes in internal $\mathrm{Ca}^{2+}$ concentration, thus accelerating eryptosis. Meanwhile, ceramide can independently induce eryptosis when RBCs undergo osmotic stress. Sphingosine 1 phosphate, a degradation product of ceramide by ceramidase, could inhibit eryptosis [41]. Ceramide generated in the plasma membrane augments membrane rigidity by stabilizing smaller lipid platforms known as lipid rafts. Therefore, the accumulation of ceramide is an indication of increased membrane fragility [42].

Ion flow also causes the abnormal morphological state of RBC. During oxidative stress, osmotic stress, accumulation of prostaglandin $\mathrm{E} 2$, and removal of $\mathrm{Cl}^{-}$processes, $\mathrm{Ca}^{2+}$ flows into the $\mathrm{RBC}$ through $\mathrm{Ca}^{2+}$-permeable cation channels. Increased intracellular calcium concentrations and membrane changes activate calcium-sensitive potassium channels, which causes outflow of $\mathrm{K}^{+}$along the concentration gradient, causing hyperpolarization of the RBC. The decreased intracellular $\mathrm{K}^{+}$causes outflow of chloride ions, resulting in a decreased osmotic pressure

What Should Be Responsible for Eryptosis in Chronic Kidney Disease? and cell shrinkage [43-45]. Meanwhile, $\mathrm{Ca}^{2+}$ activates calpain, triggering RBC membrane blebbing [46, 47]. Plasma membrane $\mathrm{Ca}^{2+}$-ATPase and plasma membrane $\mathrm{Na}^{+} / \mathrm{Ca}^{2+}$ exchanger are responsible for $\mathrm{Ca}^{2+}$ outflow, and both require ATP to overcome the enormous chemical gradient [48]. Plasma membrane $\mathrm{Ca}^{2+}$-ATPase activity gradually attenuates with the degree of renal failure [49]. Additional research regarding the mechanism of $\mathrm{Ca}^{2+}$ flow may further elucidate the process of CKD.

Moreover, the signal pathways that regulate the state of ion channels and apoptosis also affect the state of $\mathrm{Ca}^{2+}$ channels on $\mathrm{RBC}$ membranes, thereby regulating eryptosis. Phosphoinositide-dependent kinase 1 (PDK1) involves in PI3 kinase-dependent stimulation of SGK1 and activates transient receptor potential cation channel V5 $[50,51]$. Both PDK1 and the transient receptor potential channel 6 contribute to the erythrocyte $\mathrm{Ca}^{2+}$ leak and PS exposure in eryptosis [52]. Whether TEPV5 is involved in $\mathrm{Ca}^{2+}$ flow during eryptosis remains unclear. However, a study about PDK1 gene deficiency and eryptosis found that the activation of $\mathrm{Ca}^{2+}$ channels on the RBC surface was significantly inhibited, and blunted eryptosis was consistent with the reduced $\mathrm{Ca}^{2+}$ channels [53]. PDK1 also activates $\mathrm{K}^{+}$channels, inducing erythrocyte shrinkage and eryptosis [53]. Annexin A7, as a $\mathrm{Ca}^{2+} / \mathrm{GTP}$ sensor that regulates vesicle secretion, is an intracellular protein which can bind both $\mathrm{Ca}^{2+}$ and phospholipids [54]. The mice model experiment proved that the knockout of annexin A7 elevated $\mathrm{K}^{+}$channel sensitivity and PS exposure, thereby accelerating eryptosis [55]. The characteristics of eryptosis and relative measuring methods are shown in the Table 1.

RBCs with exposed PS, which are mainly recognized by macrophages in the limbic system of the spleen and $\mathrm{CD} 207^{+}$dendritic cells, are phagocytosed and cleared from the circulatory system $[56,57]$. After phagocytosis, iron in the digested erythrocytes is recycled for erythropoiesis with the catalysis of hemeoxygenase [58]. However, due to an inflammatory state, uremic toxins, and potential hypoxia in $\mathrm{CKD}$, high levels of hepcidin suppress the absorption of iron, contributing to the disturbed iron homeostasis $[59,60]$.

\section{Factors Influencing Eryptosis in CKD}

There are many clinical and physical conditions related to eryptosis including iron deficiency [61], hemolytic anemia [62], antiphospholipid syndrome [63], glucose-6-phosphate dehydrogenase deficiency [64], sickle- 
Table 1. The characteristics of eryptosis and corresponding investigation methods [144, 203-211]

\begin{tabular}{llll}
\hline Evidences of eryptosis & Detection reagents & Detection methods & Citation \\
\hline $\begin{array}{l}\text { Intracellular } \mathrm{Ca}^{2+} \text { concentration } \\
\text { Ceramide abundance }\end{array}$ & Fluo-3/4 fluorescence & Flow cytometry & {$[203,204]$} \\
PS exposure & Monoclonal antibody-based assay & Flow cytometry & {$[205]$} \\
& Annexin V & Flow cytometry & {$[144,206-$} \\
Cell volume & & Confocal microscopy & $209]$ \\
Lipid peroxidation & & Flow cytometry & {$[144]$} \\
Caspase-3 & Dye BODIPY 581/591 C11 & Flow cytometry & {$[210]$} \\
\hline
\end{tabular}

cell disease [65], and sepsis [66]. For CKD patients, the main pathophysiological factors affecting eryptosis include oxidative stress, energy depletion, uremic toxins, and vitamin $\mathrm{D}$ treatment.

\section{Oxidative Stress and Eryptosis}

As the sole oxygen carrier of the body, RBCs are periodically exposed to reactive oxygen species (ROS). In general, oxidative stress refers to oxidative damage from free radicals and redox molecules, which leads to intracellular and/or extracellular damage caused by the imbalance between oxidants and antioxidants $[67,68]$. In physiological conditions, a state of dynamic equilibrium between the production and removal of ROS is maintained within cells, called redox homeostasis [69]. When oxidative stress increases beyond the antioxidant capacity, damage gradually accumulates within the erythrocyte, resulting in molecular changes and relevant pathophysiological states [70]. Due to the lack of mitochondria and lysosomes, RBCs cannot carry out reparative processes. To alleviate damage from ROS, RBCs maintain a balance between levels of oxidants and antioxidants through nonenzymatic antioxidant and enzymatic antioxidant systems that include superoxide dismutase, catalase, glutathione peroxidase, and peroxiredoxin 2 [71, 72]. Evidence has shown that oxidative stress is negatively associated with the glomerular filtration rate and duration of dialysis [73]. In ESRD patients, glutathione reductase activity is increased [74], while that of glutathione peroxidase is attenuated [75]. During HD, the dialysis membrane worsens oxidative stress, which is further exacerbated due to the loss of antioxidants [20].

The balance between the levels of oxidants and antioxidants first develops during since the early stages of CKD. In ESRD, oxidative stress is exacerbated because of the suppressed antioxidant systems (decreased levels of vitamin $\mathrm{C}$ and selenium and disorder of the glutathione
[GSH] scavenging system) and factors that increase oxidant levels (advanced age, diabetes, and uremia) [76]. $\mathrm{GSH}$, an oxyradical scavenger, is the main nonenzymatic antioxidant system within RBCs [77]. Studies have shown that PS exposure was positively correlated with lipid peroxidation, although it was negatively correlated with the total plasma antioxidant capacity and GSH/GSSG ratio in patients with diabetic nephropathy [78]. This highlights oxidative stress and the impaired antioxidant capacity as partly responsible for eryptosis in CKD patients with diabetes. SOD1, the only form of superoxide dismutase present in mature RBCs [79], may attenuate the eryptosis. When the gene of SOD1 was knocked out, the RBCL in mice is shortened [79]. In another study, SOD1 gene knockout resulted in an increase in the number of autoantibodies and RBCs that combined with IgG as well as immune deposits in the glomerulus [80, 83]. Meanwhile, antioxidant $\mathrm{N}$-acetylcysteine administration significantly alleviated this phenomenon $[80,83]$. Under the oxidative stress, eryptosis is inhibited through cGMP-dependent protein kinase type 1 , which is stimulated by nitric oxide (NO) [81]. RBCs enzymatically produce NO from RBCNO synthase. Distinctly high levels of basal enzymatic NO and accumulation of cGMP resist the decline of NOS expression within uremic RBCs, which is a promising method to extend RBCL [82]. The cGKI-deficient mice developed anemia and splenomegaly due to the shortened lifespan of erythrocytes [212].

Oxidative stress causes the impairments in the membrane structure, permeability, and fragility of RBCs in CKD patients. ROS from $\mathrm{H}_{2} \mathrm{O}_{2}$ and hydroxyl free radicals injure $\mathrm{RBC}$ membrane proteins and lipids, resulting in the rearrangement of the erythrocyte membrane skeleton and the reduction of cell membrane stability and deformability [84]. The pivotal of these phenomena laid in the activity of microvesicles (MVs) and band 3 [85]. Generally, oxidative stress initiates eryptosis via $\mathrm{Ca}^{2+}$-depen- 


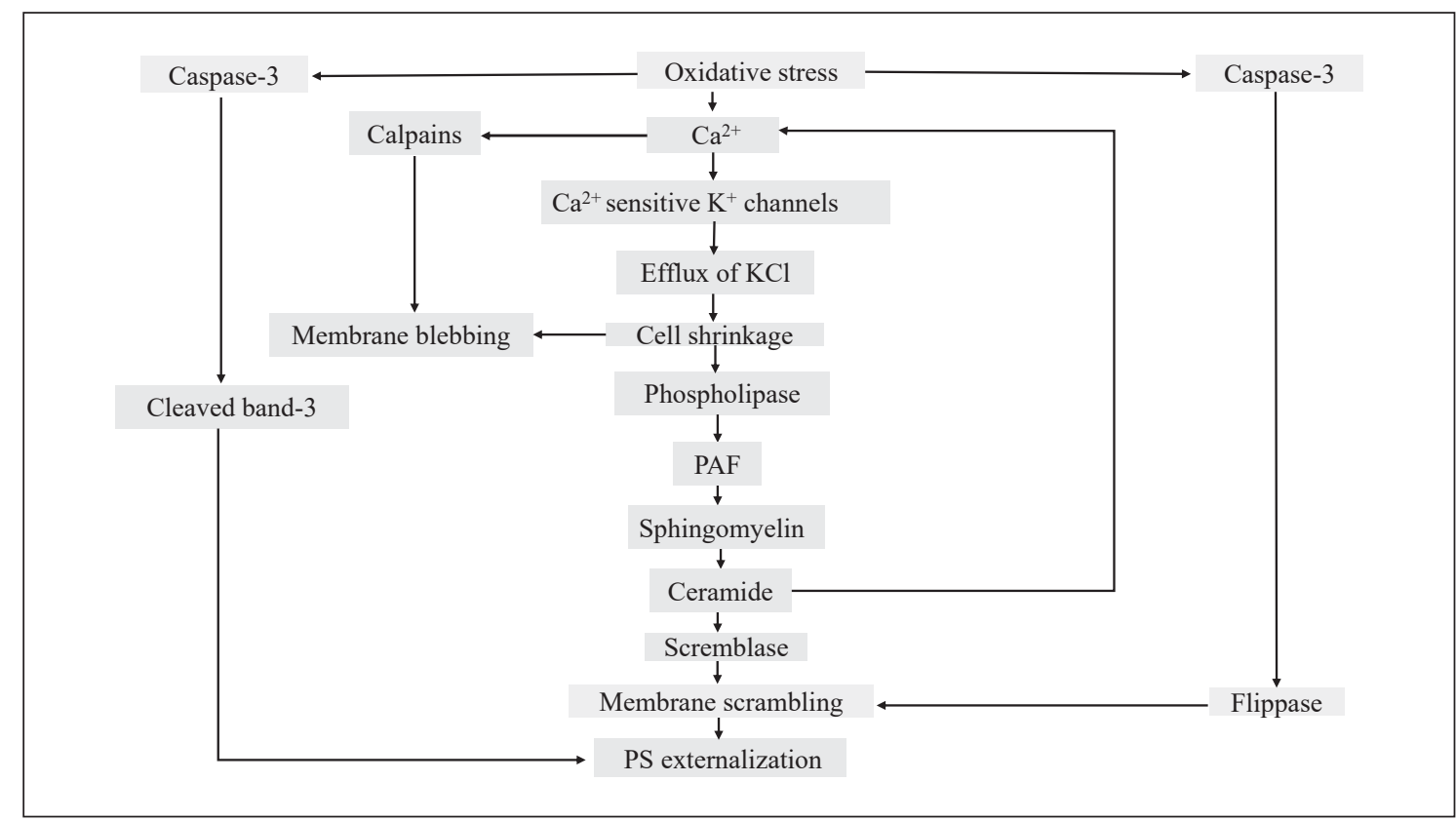

Fig. 1. Hypothesis of the eryptosis process induced by oxidative stress. PS, phosphatidylserine; PAF, plateletactivating factors.

dent or $\mathrm{Ca}^{2+}$-independent pathways. The elevated inward Ca flux mediates the PS externalization and shedding [86]. The cholesterol/phospholipid ratio is essential in maintaining the membrane fluidity. However, PS shedding disrupts this ratio, resulting in decreased membrane fluidity that influences the lifespan of RBCs [86]. In addition to activate $\mathrm{Ca}^{2+}$-permeable cation channels, oxidative stress induces eryptosis via $\mathrm{Cl}^{-}$channels [87], subsequently leading to erythrocyte membrane shrinkage [88]. PS exposure induced by oxidative stress, independently of $\mathrm{Ca}^{2+}$ concentration, is consistent with the accumulation of $\mathrm{MV}$ and band 3 in RBC, which further drives the process of eryptosis. MV release is part of the physiological RBC aging process in vivo and represents the structural change of the lipid bilayer and cytoskeleton. The increased MV release from RBCs of HD patients disturbs the ultrastructure related to membrane stability [89]. Lactadherin, a PS inhibitor, limits MV release, thus strengthening micro-vesiculation in eryptosis [90]. Band 3, also named anion exchanger 1 , allows the $\mathrm{HCO}^{-} / \mathrm{Cl}^{-}$exchange across plasma membrane, thereby contributing to cell morphology and deformability [91]. Compared with the RBCs in healthy participants, band 3 protein content in RBCs of patients with acute renal failure and CKD is markedly decreased [92]. Band 3 may undermine the adhesion between the cytoskeleton and lipid bilayer [92], thus inducing the vesiculation and affecting RBC properties [89], making the erythrocyte vulnerable to hemolysis [85]. Oxidative damage has been shown to modify the rheological properties of circulating erythrocytes, shortening their lifespan through the monocyte-macrophages system $[93,94]$. To prolong their survival, RBCs eliminate the oxidized $\mathrm{Hb}$ in the form of vesicles [84, 95].

Oxidative stress also triggers the cysteinyl-aspartatespecific proteinase (caspases). Cysteinyl-aspartate-specific proteinase-3 (caspase-3) activity in erythrocyte is considered as indirect evidence for eryptosis [96]. A published experiment showed that caspase-3 may exert effects on eryptosis by mediating flippase activity [97]. Since blocking the activity of caspases could not reverse the PS exposure, the caspases is not the only way mediating this change [97]. Notably, the $\mathrm{Ca}^{2+}$-dependent membrane scrambling does not depend on the activation of caspases [98]. When triggered by oxidative stress, caspases cleave band 3; thus, band 3 interacting with the protein 4.2 of cytoskeletal network of erythrocyte is decreased, which promotes PS translocation from the lobules to the surface of the RBC membrane and band 3 clustering [99, 100]. Additionally, PS exposure would accelerate band 3 aggregation, and the eryptotic erythrocyte would subsequently be engulfed by macrophages $[57,100]$. High caspase- 3 erythrocytes may contribute to the shortened life- 
span of uremic erythrocytes in CKD [101]. Caffeine contributes to inhibit caspase-3 activation due to its antioxidative capacity [102]. Oxidative stress disturbs erythrocyte membrane structure, increases MV, and activates caspases, all of which aggravate eryptosis that eventually leads to renal anemia. The hypothesis of eryptosis process induced by oxidative stress is shown in Figure 1.

About $10 \%$ of HD patients suffer from hypoxia during a dialysis session. This is defined as prolonged intradialytic hypoxemia, a state wherein arterial oxygen saturation falls below 90\% [103]. However, the effect of hypoxia on eryptosis is controversial. Hypoxia causes transformation of the oxygenated $\mathrm{Hb}$ into deoxygenated $\mathrm{Hb}$. Deoxygenated $\mathrm{Hb}$ removes ankyrin from band 3, resulting in increased RBC deformability [104]. However, $\mathrm{Hb}$ binding to the ligand is reduced when RBCs is incubated with acute hypoxic stimulation [105]. In a rat model of chronic hypoxia, eryptosis inhibition was attributed to the decreased intracellular $\mathrm{Ca}^{2+}$ rather than the $\mathrm{PAF} / \mathrm{ce}$ ramide pathway $[106,107]$. CKD patients, especially those suffering from respiratory distress syndrome, usually develop hypoxemia during dialysis, stimulating ROS generation $[108,109]$. The formation of redox oligomers of GAPDH and PRDX2, which is induced by over-oxidized sulfinic acid, ultimately leads to a decline in $\mathrm{RBC}$ antioxidant capacity, subsequently decreasing RBCL, and worsening eryptosis [110]. If accelerated eryptosis exceeds reactive erythropoiesis, anemia develops [111]. An in vitro study revealed the independent synergistic relationship between uremic toxins and hypoxia on eryptosis [103]. Uremic toxins and hypoxia condition exacerbate eryptosis and disturb the redox balance. Studies have also showed that both hypoxia and uremic toxins shorten RBCL and exacerbate anemia in HD patients [112].

Decreased antioxidant levels and HD treatment can exacerbate oxidative stress in CKD patients $[113,114]$. In uremic patients undergoing PD or HD treatment, oxidative stress and eryptosis were found to be enhanced [21]. Renal anemia has been shown to exacerbate oxidative stress especially in HD patients, whereas improvement of anemia may decrease oxidative stress status [113]. While several studies have found that improvement of anemia with ESA use could significantly inhibit the oxidation process $[115,116]$, another study found that ESA use had no noticeable effect on improving oxidative parameters (including plasma thiobarbituric acid-reactive substances, plasma total thiol, erythrocyte nonprotein thiol, erythrocyte glutathione peroxidase, and erythrocyte catalase) compared with the non-EPO administration group [117].
Recombinant human EPO (rhEPO) therapy could prolong erythrocyte lifespan in dialysis patients by inhibiting $\mathrm{Ca}^{2+}$ channels, thus attenuating eryptosis [118]. rhEPO also mitigates oxidative stress, which lessens the risk of cardiovascular events such as atherosclerosis [119]. However, the existing experiment indicated that mice with chronically overexpressed EPO would be more sensitive to eryptosis despite a stronger resistance against osmotic shock [120]. Therefore, rhEPO not only mitigates the oxidative stress-induced eryptosis but also weakens the rhEPO dose-related sensitivity to eryptosis. Notably, as an antioxidant, EPO exerts its effects via the NO synthase pathway in RBCs, by enhancing GSH oxidation, which is hinged on L-arginine availability [121]. This effect was also observed in ESRD patients treated with ascorbic acid [122]. These show the necessity of exploring the actual influence of antioxidant treatments.

At present, several studies have verified that antioxidants can inhibit or blunt eryptosis. These antioxidants include DMTD [123], EPO [124-126], nitroprusside [127], NO [128], vitamin C [129, 130], resveratrol [131], and cinnamaldehyde [132] (the two can have a synergistic effect), hydroxytyrosol [133], salidroside [134], thymol [135], apigenin [136], L-carnitine [137], phlorizin [138], naringin [139], temsirolimus [140], pyrogallol [141], reversine [142], sonidegib [143], chelerythrine [144], xanthohumol [145],teriflunomide [146], and ASP3026 [147]. The substances, their effective concentrations and the possible mechanisms suppressing oxidative stress have been shown in Table 2. Although in vitro experiments have proven that these substances blunt eryptosis due to their antioxidant properties, whether they alleviate eryptosis in a uremic environment still needs further investigations.

\section{Osmotic Stress and Eryptosis}

Erythrocytes are frequently exposed to the hyperosmotic environment of the renal medulla. However, contact time between erythrocytes and the renal medulla is too short to induce eryptosis [148]. Furthermore, the widely high $\mathrm{Cl}^{-}$level prevents the opening of nonselective cation channels, and urea in the medulla disturbs the sphingomyelinase [35]. These conditions protect the erythrocyte from damage when passing through the kidney.

Hyperosmotic stress is another important predisposing factor for eryptosis. First, it may enhance cyclooxygenase and increase production of prostaglandin E2, leading to the activation of calcium-sensitive cation channels [149]. Second, it stimulates phospholipase A2 with or 
Table 2. The antioxidative reagents' effective concentrations and their possible mechanisms relieving eryptosis [128, 129, 132-134, 137, $139,142-147]$

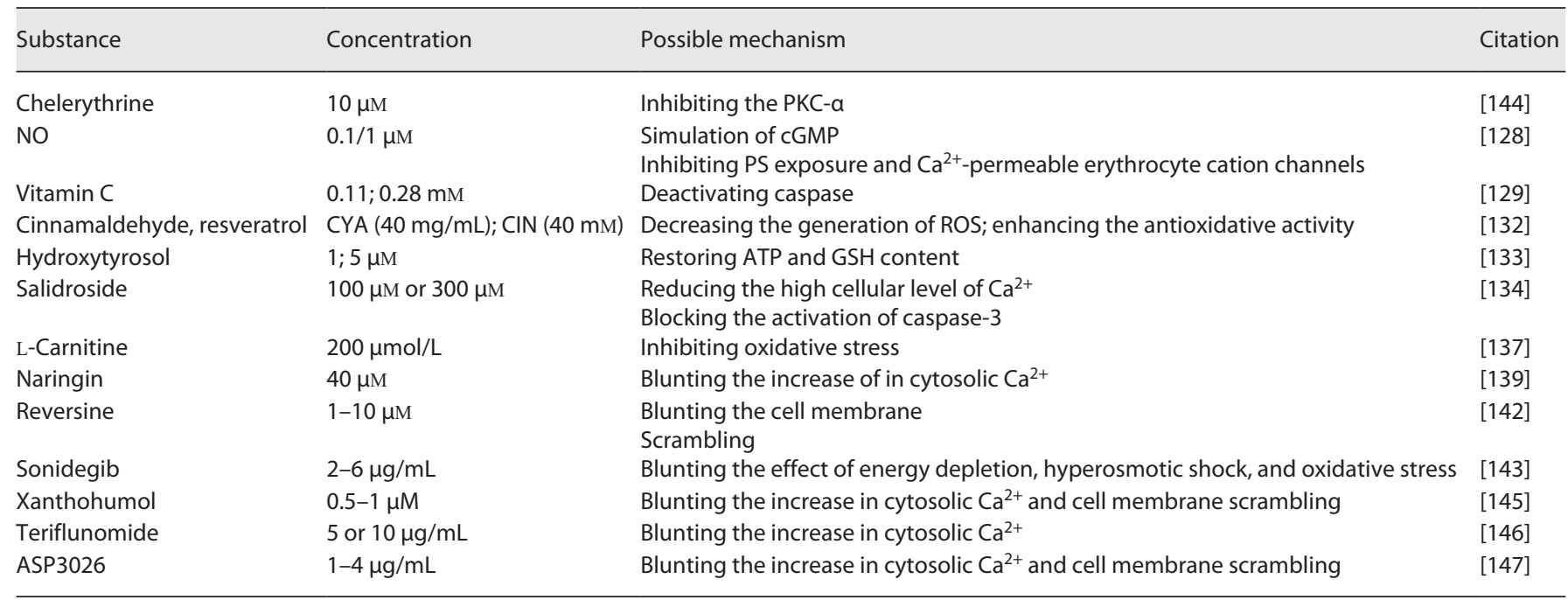

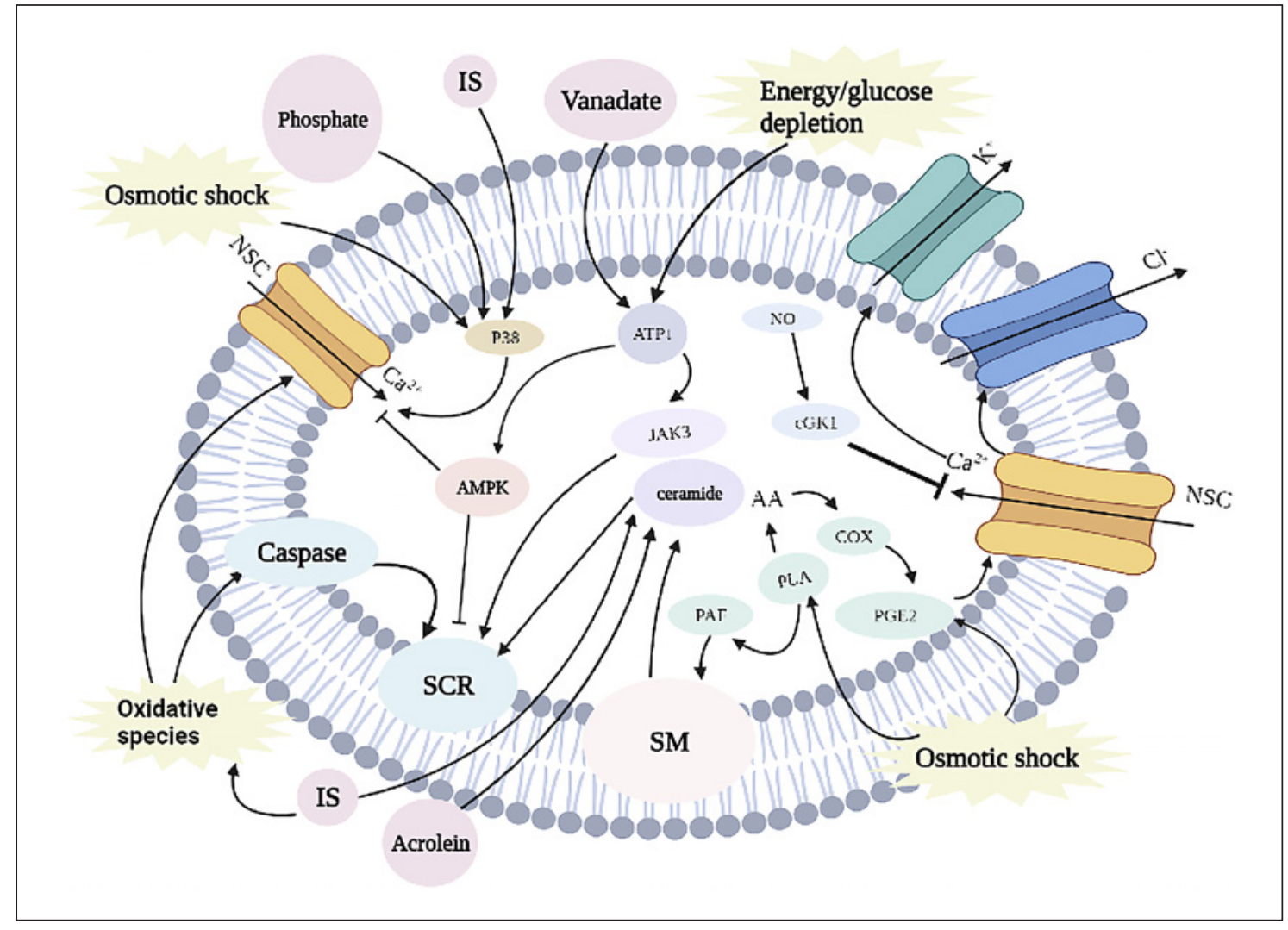

Fig. 2. Possible mechanisms of eryptosis provoked by main factors. Generally, the microenvironment of CKD, including the enhanced oxidative stress, the energy depletion, hyperosmotic stress, the uremic toxins (phosphate, IS, and acrolein), and so on, disturb erythrocyte membrane structure and accelerate the PS exposure of the erythrocyte through formatting ceramide, elevating intracellular $\mathrm{Ca}^{2+}$ concentration, and activating caspase- 3 and finally accelerate the eryptosis. (created with BioRender.com). cGK1, cGMP-dependent protein kinase type 1; COX, cyclooxygenase; GC, Gardos channel; IS, indoxyl sulfate; NO, nitric oxide; NSC, nonselective cation channels; PAF, platelet-activating factors; PLA, phospholipase; PGE2, prostaglandin E2; SCR, scrambling enzyme; SM, sphingomyelinase. 
without PAF release [149], which accelerates the synthesis of ceramide by activating sphingomyelinase [34]. This process is shown in Figure 2. In a hyperglycemic environment, a series of events related to eryptosis have been observed in RBCs [123], such as the accumulation of advanced glycosylation products, augmented oxidative stress, and subsequent changes in morphology and structure [78]. Experiments have shown that a hyperosmotic environment could enhance the $\mathrm{Ca}^{2+}$-dependent cation channel activity of the RBC membrane [36]. The changes above were also confirmed in patients with diabetes mellitus [150], which seems to partly explain why diabetes patients are more prone to renal anemia. The microenvironments in patients with type 2 diabetes mellitus alters lipid-protein interactions, which induces oxidative stress and enzyme peroxidation that attenuates erythrocyte membrane fluidity [151]. Additionally, the corresponding oxidative stress will reduce the lifespan and properties of erythrocytes [152]. Generally, the oxidative stress in diabetes patients intensifies damage caused by $\mathrm{Hb}$ glycation of band 3 protein [153]. Therefore, hyperglycemic environment will destroy band 3 on the surface of erythrocytes, which will not only alter their shape and rheological properties but also reduce the lifespan. In addition, a significantly elevated concentration of methylglyoxal has been observed in patients with hyperglycemia, which results in PS exposure on the surface of erythrocytes [154].

\section{Energy Depletion and Eryptosis}

Due to the lack mitochondria, mature RBCs obtain energy through glycolysis and the pentose phosphate pathway. A low ATP supply will activate AMP-activated protein kinase (AMPK) to rapidly regulate the corresponding signal transduction pathways, including fatty-acid oxidation and autophagy [155].

AMPK, an energy-sensing enzyme, is a heterotrimer composed of $\alpha \beta \gamma$ subunits [156], of which, the $\alpha$ and $\beta$ subunits can alleviate damage caused by oxidative stress to the RBC [157]. Its $\gamma$ subunit detects the energy state in cells through a competitive combination with AMP and ATP, among which the $\gamma 1$ subunit is a necessary structure to maintain the elasticity of the RBC membrane [158]. The limited capability to synthesize energy makes erythrocytes more sensitive to a deficient energy supply. When the ratio of ATP/AMP declines, the AMPK activation seems to inhibit eryptosis caused by energy depletion [159]. During hypoxia, the ADORA2B-AMPK signal causes an increase in 2,3-BPG, which promotes oxygen transport to attenuate the hypoxia environment, delaying the progress of CKD progression [160].
AMPK is not only involved in the energy supply modulation of RBC but also prolongs their lifespan, probably by attenuating the effects of oxidative stress. AMPKal deletion leads to the clearance of premature erythrocytes with abnormal structures and disturbs the oxidant-antioxidant balance. The significantly reduced osmotic fragility of RBCs was observed in AMPKal deficient mice, which may have prevented RBCs from passing through the splenic sinus, leading to its premature clearance [161].

In addition to the above functions, AMPK also contributes to the differentiation and maturation of RBCs and maintains their integrity and survival $[162,163]$. After energy depletion, activated AMPK inhibits nonselective cation channel, impeding $\mathrm{Ca}^{2+}$ influx and preventing changes in erythrocytes. AMPK disturbs the scrambling enzyme, which aids in the translocation of PS that subsequently results in the elimination of the eryptotic erythrocyte. Notably, AMPK does not prevent eryptosis but only blunts it [47]. Unlike AMPK, levels of phosphorylated Janus kinase 3 on the RBC surface increase when there is energy depletion, resulting in the downregulation of $\mathrm{Na}^{+}-\mathrm{K}^{+}$-ATPase activity and reduces ATP consumption to regulate energy balance [164]. The above mechanisms were shown in the Figure 2.

$\mathrm{CK} 1 \alpha$ is a positive regulator of eryptosis, AMPK alters the expression of CK1 $a$ in erythrocyte progenitor cells. An experiment revealed that decreased CK1 a levels in AMPKa1-deficient murine erythrocytes would augment $\mathrm{Ca}^{2+}$ influx together with membrane scrambling when stimulated by glucose depletion and oxidative stress [165]. Since erythrocytes lack nuclei, it is unknown whether AMPK regulates the CK1 $\alpha$ before erythrocyte maturation or alters the conformation of CK1 $\alpha$ in mature erythrocytes.

\section{Uremic Toxins and Eryptosis}

In addition to oxidative stress and energy depletion, the accumulation of multiple toxins in CKD accelerates eryptosis. The uremic toxins, mainly derived from selfmetabolism and protein digestion, are responsible for eryptosis in CKD patients. Generally, uremic toxins are divided into water-soluble toxins, protein-bound toxins, and intermediate molecules [166]. The combination with albumin may prevent the clearance of uremic toxins by dialysis [167]. In ESRD patients, eryptosis is largely influenced by the plasma composition. This was revealed when RBCs of healthy individuals in the plasma of ESRD patients significantly increased the percentage of PS externalization [168]. The mean RBCL in healthy and HD patients were $128 \pm 28$ and $89 \pm 28$ days, respectively 
[169]. At present, various studies have found that some uremic toxins trigger eryptosis, such as indoxyl sulfate (IS) [170], phosphate [171], acrolein [172], vanadate [173], methylglyoxal [154], and indole-3-acetic acid (IAA) [95].

Tryptophan is metabolized by intestinal bacteria into indole, which is oxidized in the liver and combined with sulfate to synthesize IS [174]. IS, a protein-bound uremic toxin, binds so tightly to plasma proteins that their combination cannot be effectively eliminated through the glomeruli. Therefore, IS mainly relies on organic anion transporter 1 (OAT1) and 3 (OAT3) of the renal tubular epithelial cells for their transport from the blood to the renal tubular cells [175]. The transport process from the renal tubular cells to the renal tubule lumen depends on ABCG2 [176]. Clinical trials have shown that IS is associated with cardiovascular events [177, 178], which are probably related to the high level of oxidative stress within endothelial cells [179].

An advanced study found that the transport efficiency of protein-bound uremic toxins (both influx and efflux processes) increased according to the following sequence: $\mathrm{HA}<$ IS $<$ pCS $<$ IAA [180]. After HD, IS concentration retains at a high level compared to healthy [112]. IS increases cytosolic $\mathrm{Ca}^{2+}$ concentration and stimulates erythrocyte cell membrane scrambling, resulting in PS exposure on the cell surface [170]. Additionally, IS is speculated to increase levels of ceramide, which is a contributing factor that aggravates eryptosis [170]. The present research show that IS seems to initiate eryptosis through GSH-dependent mechanisms [181]. The transport and metabolism of several uremic toxins, including IS, is carried out by the OAT1 and OAT3 of renal tubular epithelial cells $[175,182]$. Evidence has shown that IS and ROS synergistically induce eryptosis [103]. IS also activates p38 MAP kinase [183], an apoptosis-related protein, which further exacerbates eryptosis [184].

Interestingly, both IS and IAA induce PS externalization and release of RBC-derived microparticles (MPs), which enhances the thrombus formation [95]. During apoptosis, PS translocation is accompanied by MPs, which not only expose PS but also express membrane antigens on their surfaces [185]. FXa and prothrombinase complexes bind to RBC-derived MPs and the externalized PS, acting on the coagulation cascade, enhancing thrombin generation [95]. Consequently, the microcirculation in $\mathrm{CKD}$ is exacerbated, and the cardiovascular risk increases.

Although phosphate is necessary for cell metabolism and growth, excess amounts are harmful especially when there is dysfunction of renal phosphate excretion [186]. A dysfunctional kidney cannot effectively excrete discharge phosphates, resulting in its accumulation [187]. P38 MAP kinase, one of the downstream target signals of phospholipase 2, may participate in the process above. The deposited calcium phosphate crystals stimulate the activity of p38 kinase, which further stimulate the production of PAFs [111].

Similar to IS, high levels of vanadate in CKD patients promote the effect of $\mathrm{Ca}^{2+}$ on eryptosis. Vanadate inhibits ATP production, which results in an energy-deficient state that induces eryptosis [188]. Vanadate also regulates the activity of glyceraldehyde-3-p dehydrogenase by exchanging the redox state of the enzyme [189]. This inhibits the glycolysis within RBCs, resulting in an energy-deficient state [189]. Acrolein stimulates the suicidal death of erythrocytes by stimulating ceramide formation with subsequent sensitization of the erythrocytes to cytosolic $\mathrm{Ca}^{2+}$ concentrations [172]. The possible mechanisms of eryptosis induced by uremic toxins are also shown in Figure 2.

\section{Other Factors Influencing Eryptosis}

Aside from maintaining calcium levels and regulating phosphorus metabolism, vitamin D plays a role in promoting RBC proliferation and improving iron utilization [190]. Actually, anemia has been noted in 49\% of 25-hydroxyvitamin D-deficient subjects [191]. Clinical studies have consistently confirmed the correlation between 25-hydroxyvitamin D and/or 1,25-dihydroxyvitamin D deficiency and the reduction of $\mathrm{Hb}$ levels in early stages of CKD [192]. FGF23, in cooperation with the membrane protein klotho, downregulates the formation of $1 \alpha, 25-$ dihydroxyvitamin D. Anemia in klotho-deficient mice was attributed to the severely impaired erythropoiesis and enhanced sensitivity to eryptosis [193, 194]. Mice with a high-vitamin $\mathrm{D}$ diet also manifested elevated eryptosis when erythrocytes were incubated in an energy-depleted microenvironment, or hyperosmotic shock was induced [195].

Intriguingly, although 1,25-hydroxyvitamin $\mathrm{D}$ promoted $\mathrm{Ca}^{2+}$ influx in nucleated cells [196], vitamin D treatment did not show any correlation with increasing intracellular $\mathrm{Ca}^{2+}$ concentration in RBCs, which subsequently triggers eryptosis [195]. The same conclusion was proved in Klotho deficiency situation, which in some extents speculated the role of relative genomic regulation [193]. Vitamin D does not directly regulate eryptosis, but it participates by influencing signal molecules related to eryptosis, which presumably affects the regulation of ce- 


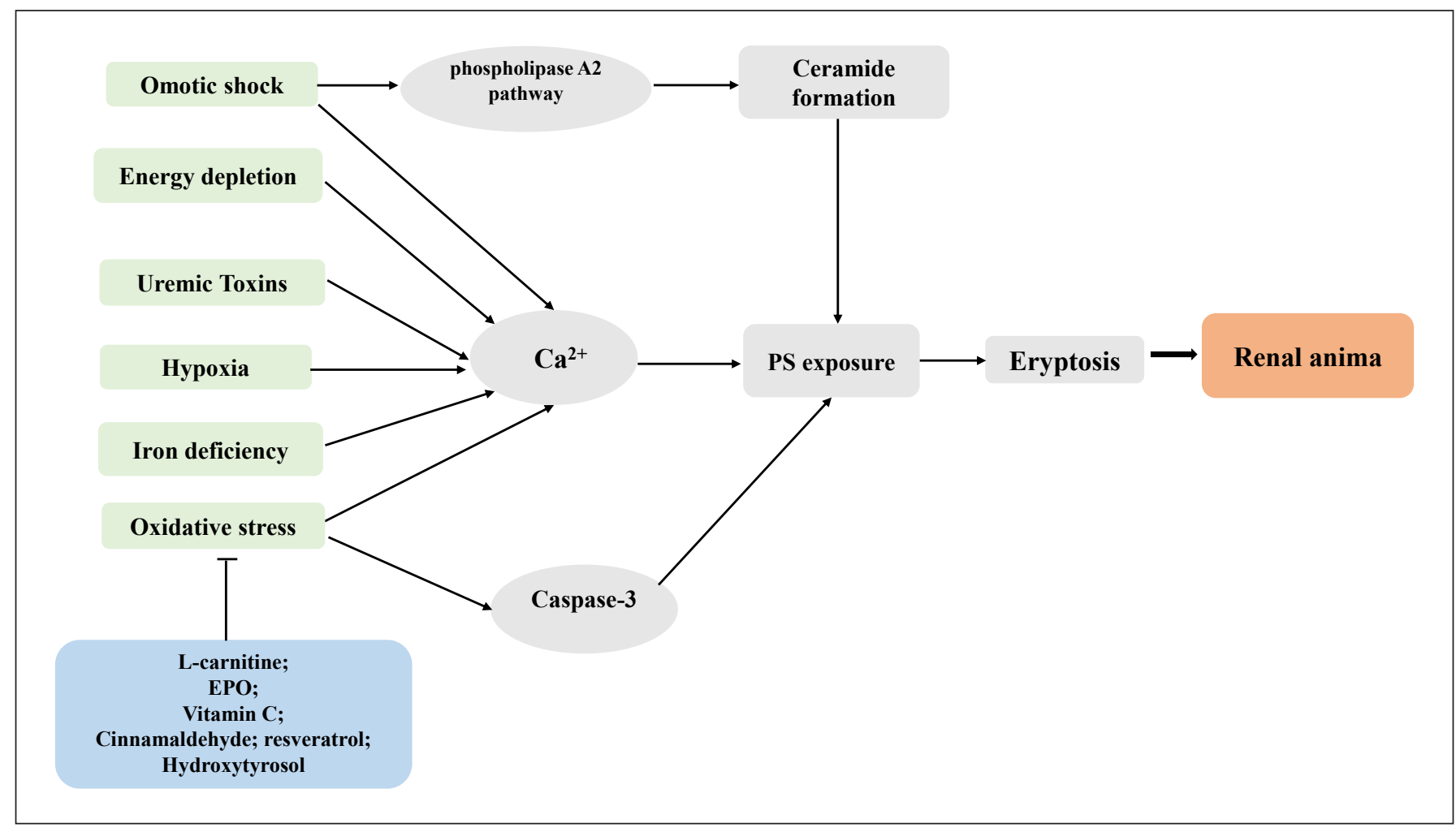

Fig. 3. Overview of eryptosis in CKD. PS, phosphatidylserine; caspase-3, cysteinyl-aspartate-specific proteinase-3; EPO, erythropoietin.

ramide synthesis and activity of protein kinase C [197]. Vitamin D increases RBC sensitivity to stressful environments (such as osmotic shock and energy depletion).

Iron deficiency stands out among the mechanisms that contribute to anemia in the setting of a reduced kidney function [59]. Long-term EPO therapy without iron supplement can aggravate iron depletion. In this condition, enhanced programmed cell death of erythrocytes is observed [198]. The mechanism of iron deficiency-induced eryptosis partly induces the activity of the $\mathrm{Ca}^{2+}$-permeable cation channel. Iron-deficient erythrocytes, with lower level of $\mathrm{Hb}$, have reduced cell volumes, resulting in an enhanced activity of the nonselective cation channels [199]. Subsequent PS exposure scrambles the cell membrane [200]. Meanwhile, cellular $\mathrm{KCl}$ loss and cell shrinkage occur due to the activation of $\mathrm{Ca}^{2+}$-sensitive potassium channel (Gardos channels) $[45,201]$. In one study, the ROS level in irondeficient mice was significantly higher than that of the control group [202], which contributed to the clearance of eryptotic erythrocytes.

\section{Conclusion}

In $\mathrm{CKD}$, various factors, including energy depletion, high concentrations of uremic toxins environment, and oxidative stress increase the permeability of $\mathrm{Ca}^{2+}$ channels, dysregulate the cellular framework, and expose PS, resulting in eryptosis, as it was shown in Figure 3. Once these eryptosis evidences are recognized, the elimination of abnormal RBCs will be accelerated. This review highlights the role of eryptosis in exacerbating the destruction of erythrocytes, worsening renal anemia. From this point of view, targeted drugs that extend the RBCLs are promising treatments for correcting anemia in CKD patients.

\section{Conflict of Interest Statement}

The authors have no conflicts of interest to declare. 


\section{Funding Sources}

Primary funding source and grant support were provided by the Natural Science Foundation of Shandong (ZR2021MH394) and the Health commission of Shandong Province (No.2020M078).

\section{Author Contributions}

Dongxin Li drafted the manuscript, and Xujuan Zheng helped to draft the manuscript. Xujuan Zheng, Yunxia Zhang, Xiangling $\mathrm{Li}$, Xuexun Chen, and Yonghua Yin analyzed the current literature and revised the manuscript. Dongxin Li, Jingwen $\mathrm{Hu}$, and Jialin $\mathrm{Li}$ designed the figures and tables. Min Guo and Xiangming Wang conceived the idea, carried out the implementation, and supervised the drafting.

\section{References}

1 Foley RN, Parfrey PS, Harnett JD, Kent GM, Murray DC, Barre PE. The impact of anemia on cardiomyopathy, morbidity, and and mortality in end-stage renal disease. Am J Kidney Dis. 1996;28(1):53-61.

2 Stauffer ME, Fan T. Prevalence of anemia in chronic kidney disease in the United States. PLoS One. 2014;9(1):e84943.

3 Evans M, Bower H, Cockburn E, Jacobson SH, Barany P, Carrero JJ. Contemporary management of anaemia, erythropoietin resistance and cardiovascular risk in patients with advanced chronic kidney disease: a nationwide analysis. Clin Kidney J. 2020;13(5): $821-7$.

4 Sallée M, Dou L, Cerini C, Poitevin S, Brunet $\mathrm{P}$, Burtey S. The aryl hydrocarbon receptoractivating effect of uremic toxins from tryptophan metabolism: a new concept to understand cardiovascular complications of chronic kidney disease. Toxins. 2014;6(3):934-49.

5 Liu M, Li XC, Lu L, Cao Y, Sun RR, Chen S, et al. Cardiovascular disease and its relationship with chronic kidney disease. Eur Rev Med Pharmacol Sci. 2014;18(19):2918-26.

6 Costa E, Rocha S, Rocha-Pereira P, Nascimento H, Castro E, Miranda V, et al. Neutrophil activation and resistance to recombinant human erythropoietin therapy in hemodialysis patients. Am J Nephrol. 2008;28(6):93540.

7 Spinowitz B, Pecoits-Filho R, Winkelmayer WC, Pergola PE, Rochette S, ThompsonLeduc $\mathrm{P}$, et al. Economic and quality of life burden of anemia on patients with CKD on dialysis: a systematic review. J Med Econ. 2019;22(6):593-604.

8 van der Putten K, Braam B, Jie KE, Gaillard CA. Mechanisms of disease: erythropoietin resistance in patients with both heart and kidney failure. Nat Clin Pract Nephrol. 2008; $4(1): 47-57$.

9 Adamson JW. Hyporesponsiveness to erythropoiesis stimulating agents in chronic kidney disease: the many faces of inflammation. Adv Chronic Kidney Dis. 2009;16(2):76-82.

10 René É, Lazrak HH, Laurin LP, Elftouh N, Vallée M, Lafrance JP. Association of erythropoiesis-stimulating agents and the incidence risk of cancer diagnosis among chronic dialysis patients: a nested case-control study. Nephrol Dial Transplant. 2017;32(6):1047-52.
11 Regidor DL, Kopple JD, Kovesdy CP, Kilpatrick RD, McAllister CJ, Aronovitz J, et al. Associations between changes in hemoglobin and administered erythropoiesis-stimulating agent and survival in hemodialysis patients. J Am Soc Nephrol. 2006;17(4):1181-91.

12 Pérez-García R, Varas J, Cives A, Martín-Malo A, Aljama P, Ramos R, et al. Increased mortality in haemodialysis patients administered high doses of erythropoiesis-stimulating agents: a propensity score-matched analysis. Nephrol Dial Transplant. 2018;33(4):690-9.

13 Tossidou I, Teng B, Worthmann K, MüllerDeile J, Jobst-Schwan T, Kardinal C, et al. Tyrosine phosphorylation of CD2AP affects stability of the slit diaphragm complex. J Am Soc Nephrol. 2019;30(7):1220-37.

14 Locatelli F, Del Vecchio L, Luise MC. Current and future chemical therapies for treating anaemia in chronic kidney disease. Expert Opin Pharmacother. 2017;18(8):781-8.

15 Charytan DM, Pai AB, Chan CT, Coyne DW, Hung AM, Kovesdy CP, et al. Considerations and challenges in defining optimal iron utilization in hemodialysis. J Am Soc Nephrol. 2015;26(6):1238-47.

16 Li JH, Luo JF, Jiang Y, Ma YJ, Ji YQ, Zhu GL, et al. Red blood cell lifespan shortening in patients with early-stage chronic kidney disease. Kidney Blood Press Res. 2019;44(5):1158-65.

17 Coles GA, Cavill I. Erythropoiesis in the anaemia of chronic renal failure: the response to CAPD. Nephrol Dial Transplant. 1986;1(3): 170-4.

18 Bonan NB, Steiner TM, Kuntsevich V, Virzi GM, Azevedo M, Nakao LS, et al. Uremic toxicity-induced eryptosis and monocyte modulation: the erythrophagocytosis as a novel pathway to renal anemia. Blood Purif. 2016; 41(4):317-23.

19 Ishikawa Y, Gohda T, Tanimoto M, Omote K, Furukawa M, Yamaguchi S, et al. Effect of exercise on kidney function, oxidative stress, and inflammation in type 2 diabetic KK-A(y) mice. Exp Diabetes Res. 2012;2012:702948.

20 Daenen K, Andries A, Mekahli D, Van Schepdael A, Jouret F, Bammens B. Oxidative stress in chronic kidney disease. Pediatr Nephrol. 2019;34(6):975-91.

21 Bissinger R, Artunc F, Qadri SM, Lang F. Reduced erythrocyte survival in uremic patients under hemodialysis or peritoneal dialysis. Kidney Blood Press Res. 2016;41(6):966-77.
22 Vos FE, Schollum JB, Coulter CV, Doyle TC, Duffull SB, Walker RJ. Red blood cell survival in long-term dialysis patients. Am J Kidney Dis. 2011;58(4):591-8.

23 Kodippili GC, Spector J, Kang GE, Liu H, Wickrema A, Ritchie K, et al. Analysis of the kinetics of band 3 diffusion in human erythroblasts during assembly of the erythrocyte membrane skeleton. Br J Haematol. 2010; 150(5):592-600.

24 Nunomura W, Parra M, Hebiguchi M, Sawada K, Mohandas N, Takakuwa Y. Marked difference in membrane-protein-binding properties of the two isoforms of protein 4.1R expressed at early and late stages of erythroid differentiation. Biochem J. 2009;417(1):141-8.

25 Hanspal M, Hanspal JS, Kalraiya R, Palek J. The expression and synthesis of the band 3 protein initiates the formation of a stable membrane skeleton in murine Rauschertransformed erythroid cells. Eur J Cell Biol. 1992;58(2):313-8.

26 Wickrema A, Koury ST, Dai CH, Krantz SB. Changes in cytoskeletal proteins and their mRNAs during maturation of human erythroid progenitor cells. J Cell Physiol. 1994; 160(3):417-26.

27 Palis J. Primitive and definitive erythropoiesis in mammals. Front Physiol. 2014;5:3.

$28 \mathrm{Ji}$ P. New insights into the mechanisms of mammalian erythroid chromatin condensation and enucleation. Int Rev Cell Mol Biol. 2015;316:159-82.

29 Deleschaux C, Moras M, Lefevre SD, Ostuni MA. An overview of different strategies to recreate the physiological environment in experimental erythropoiesis. Int J Mol Sci. 2020; 21(15):5263.

30 An X, Mohandas N. Erythroblastic islands, terminal erythroid differentiation and reticulocyte maturation. Int J Hematol. 2011;93(2): $139-43$.

31 Wickrema A, Crispino JD. Erythroid and megakaryocytic transformation. Oncogene. 2007;26(47):6803-15.

32 Mairbäurl H, Schulz S, Hoffman JF. Cation transport and cell volume changes in maturing rat reticulocytes. Am J Physiol Cell Physiol. 2000;279(5):C1621-30.

33 Pyrshev KA, Klymchenko AS, Csúcs G, Demchenko AP. Apoptosis and eryptosis: striking differences on biomembrane level. Biochim Biophys Acta Biomembr. 2018;1860(6):1362-71. 
34 Lang PA, Kempe DS, Myssina S, Tanneur V, Birka C, Laufer S, et al. PGE(2) in the regulation of programmed erythrocyte death. Cell Death Differ. 2005;12(5):415-28.

35 Lang KS, Myssina S, Lang PA, Tanneur V, Kempe DS, Mack AF, et al. Inhibition of erythrocyte phosphatidylserine exposure by urea and Cl. Am J Physiol Renal Physiol. 2004; 286(6):F1046-53.

$36 \mathrm{Xu} \mathrm{W}$, Peng F, Deng Y, Fan X, Li N. The emerging roles of eryptosis in liver diseases. Transfus Clin Biol. 2019;26(4):336-40.

37 Ayi K, Lu Z, Serghides L, Ho JM, Finney C, Wang JCY, et al. CD47-SIRPa interactions regulate macrophage uptake of plasmodium falciparum-infected erythrocytes and clearance of malaria in vivo. Infect Immun. 2016; 84(7):2002-11.

38 Jeffries KA, Krupenko NI. Ceramide signaling and p53 pathways. Adv Cancer Res. 2018; 140:191-215.

39 Lang KS, Myssina S, Brand V, Sandu C, Lang PA, Berchtold S, et al. Involvement of ceramide in hyperosmotic shock-induced death of erythrocytes. Cell Death Differ. 2004;11(2): 231-43.

40 Lang PA, Kempe DS, Tanneur V, Eisele K, Klarl BA, Myssina S, et al. Stimulation of erythrocyte ceramide formation by plateletactivating factor. J Cell Sci. 2005;118(Pt 6): 1233-43.

41 Signoretto E, Zierle J, Bhuyan AA, Castagna $M$, Lang F. Ceranib-2-induced suicidal erythrocyte death. Cell Biochem Funct. 2016;34(5): 359-66.

42 Lang E, Bissinger R, Gulbins E, Lang F. Ceramide in the regulation of eryptosis, the suicidal erythrocyte death. Apoptosis. 2015; 20(5):758-67.

43 Mock DM, Matthews NI, Zhu S, Strauss RG Schmidt RL, Nalbant D, et al. Red blood cell (RBC) survival determined in humans using RBCs labeled at multiple biotin densities. Transfusion. 2011;51(5):1047-57.

44 Dholakia U, Bandyopadhyay S, Hod EA, Prestia KA. Determination of RBC survival in C57BL/6 and C57BL/6-Tg(UBC-GFP) mice. Comp Med. 2015;65(3):196-201.

45 Brugnara C, de Franceschi L, Alper SL. Inhibition of $\mathrm{Ca}(2+)$-dependent $\mathrm{K}+$ transport and cell dehydration in sickle erythrocytes by clotrimazole and other imidazole derivatives. J Clin Invest. 1993;92(1):520-6.

46 Bogdanova A, Makhro A, Wang J, Lipp P, Kaestner L. Calcium in red blood cells-a perilous balance. Int J Mol Sci. 2013;14(5):984872.

47 Lang F, Gulbins E, Lang PA, Zappulla D, Föller M. Ceramide in suicidal death of erythrocytes. Cell Physiol Biochem. 2010;26(1): 21-8.

48 Brini M, Carafoli E. The plasma membrane $\mathrm{Ca}^{2}+$ ATPase and the plasma membrane sodium calcium exchanger cooperate in the regulation of cell calcium. Cold Spring Harb Perspect Biol. 2011;3(2):a004168.
49 Polak-Jonkisz D, Purzyc L, Laszki-Szczachor $\mathrm{K}$, Musial K, Zwolinska D. The endogenous modulators of $\mathrm{Ca} 2+-\mathrm{Mg} 2+$-dependent ATPase in children with chronic kidney disease (CKD). Nephrol Dial Transplant. 2010; 25(2):438-44.

50 Lang F, Böhmer C, Palmada M, Seebohm G, Strutz-Seebohm N, Vallon V. (Patho)physiological significance of the serum- and glucocorticoid-inducible kinase isoforms. Physiol Rev. 2006;86(4):1151-78.

51 Palmada M, Poppendieck S, Embark HM, van de Graaf SF, Boehmer C, Bindels RJ, et al. Requirement of PDZ domains for the stimulation of the epithelial $\mathrm{Ca} 2+$ channel TRPV 5 by the NHE regulating factor NHERF2 and the serum and glucocorticoid inducible kinase SGK1. Cell Physiol Biochem. 2005;15(1-4): $175-82$.

52 Foller M, Kasinathan RS, Koka S, Lang C, Shumilina E, Birnbaumer L, et al. TRPC6 contributes to the $\mathrm{Ca}(2+)$ leak of human erythrocytes. Cell Physiol Biochem. 2008;21(1-3): 183-92.

53 Föller M, Mahmud H, Koka S, Lang F. Reduced Ca2+ entry and suicidal death of erythrocytes in PDK1 hypomorphic mice. Pflugers Arch. 2008;455(5):939-49.

54 Abed M, Balasaheb S, Towhid ST, Daniel C, Amann K, Lang F. Adhesion of annexin 7 deficient erythrocytes to endothelial cells. PLoS One. 2013;8(2):e56650.

55 Lang E, Lang PA, Shumilina E, Qadri SM, Kucherenko Y, Kempe DS, et al. Enhanced eryptosis of erythrocytes from gene-targeted mice lacking annexin A7. Pflugers Arch. 2010; 460(3):667-76.

56 Larsson A, Hult A, Nilsson A, Olsson M, Oldenborg PA. Red blood cells with elevated cytoplasmic $\mathrm{Ca}(2+)$ are primarily taken up by splenic marginal zone macrophages and CD207+ dendritic cells. Transfusion. 2016; 56(7):1834-44.

57 Lang E, Lang F. Mechanisms and pathophysiological significance of eryptosis, the suicidal erythrocyte death. Semin Cell Dev Biol. 2015; 39:35-42.

58 Ganz T. Systemic iron homeostasis. Physiol Rev. 2013;93(4):1721-41.

59 Batchelor EK, Kapitsinou P, Pergola PE, Kovesdy CP, Jalal DI. Iron deficiency in chronic kidney disease: updates on pathophysiology, diagnosis, and treatment. J Am Soc Nephrol. 2020;31(3):456-68.

60 Ganz T. Hepcidin, a key regulator of iron metabolism and mediator of anemia of inflammation. Blood. 2003;102(3):783-8.

61 Pretorius E, Bester J, Kell DB. A bacterial component to alzheimer's-type dementia seen via a systems biology approach that links iron dysregulation and inflammagen shedding to disease. J Alzheimers Dis. 2016;53(4): 1237-56.

62 Banerjee D, Saha S, Basu S, Chakrabarti A. Porous red cell ultrastructure and loss of membrane asymmetry in a novel case of hemolytic anemia. Eur J Haematol. 2008;81(5):399-402.
63 Vomero M, Finucci A, Barbati C, Colasanti T, Ceccarelli F, Novelli L, et al. Increased eryptosis in patients with primary antiphospholipid syndrome (APS): a new actor in the pathogenesis of APS. Clin Exp Rheumatol. 2021; 39(4):838-43.

64 Ganesan S, Chaurasiya ND, Sahu R, Walker LA, Tekwani BL. Understanding the mechanisms for metabolism-linked hemolytic toxicity of primaquine against glucose 6-phosphate dehydrogenase deficient human erythrocytes: evaluation of eryptotic pathway. Toxicology. 2012;294(1):54-60.

65 Nader E, Romana M, Guillot N, Fort R, Stauffer E, Lemonne N, et al. Association between nitric oxide, oxidative stress, eryptosis, red blood cell microparticles, and vascular function in sickle cell anemia. Front Immunol. 2020;11:551441.

66 Kempe DS, Akel A, Lang PA, Hermle T, Biswas R, Muresanu J, et al. Suicidal erythrocyte death in sepsis. J Mol Med. 2007;85(3): 273-81.

67 Sies H. Oxidative stress: concept and some practical aspects. Antioxidants. 2020;9(9): 852

68 Sies H. Oxidative stress: a concept in redox biology and medicine. Redox Biol. 2015;4: 180-3.

69 Tsutsui H, Kinugawa S, Matsushima S. Oxidative stress and heart failure. Am J Physiol Heart Circ Physiol. 2011;301(6):H2181-90.

70 Bardyn M, Tissot JD, Prudent M. Oxidative stress and antioxidant defenses during blood processing and storage of erythrocyte concentrates. Transfus Clin Biol. 2018;25(1):96-100.

71 Gonzales R, Auclair C, Voisin E, Gautero H, Dhermy D, Boivin P. Superoxide dismutase, catalase, and glutathione peroxidase in red blood cells from patients with malignant diseases. Cancer Res. 1984;44(9):4137-9.

72 Lee TH, Kim SU, Yu SL, Kim SH, Park DS, Moon HB, et al. Peroxiredoxin II is essential for sustaining life span of erythrocytes in mice. Blood. 2003;101(12):5033-8.

73 Terawaki H, Yoshimura K, Hasegawa T, Matsuyama Y, Negawa T, Yamada K, et al. Oxidative stress is enhanced in correlation with renal dysfunction: examination with the redox state of albumin. Kidney Int. 2004;66(5): 1988-93.

74 Ceballos-Picot I, Witko-Sarsat V, MeradBoudia M, Nguyen AT, Thévenin M, Jaudon $\mathrm{MC}$, et al. Glutathione antioxidant system as a marker of oxidative stress in chronic renal failure. Free Radic Biol Med. 1996;21(6):84553.

75 Roxborough HE, Mercer C, McMaster D, Maxwell AP, Young IS. Plasma glutathione peroxidase activity is reduced in haemodialysis patients. Nephron. 1999;81(3):278-83.

76 Locatelli F, Canaud B, Eckardt KU, Stenvinkel $\mathrm{P}$, Wanner C, Zoccali C. Oxidative stress in end-stage renal disease: an emerging threat to patient outcome. Nephrol Dial Transplant. 2003;18(7):1272-80. 
77 Cimen MY. Free radical metabolism in human erythrocytes. Clin Chim Acta. 2008; 390(1-2):1-11.

78 Calderón-Salinas JV, Muñoz-Reyes EG, Guerrero-Romero JF, Rodríguez-Morán M, Bracho-Riquelme RL, Carrera-Gracia MA, et al. Eryptosis and oxidative damage in type 2 diabetic mellitus patients with chronic kidney disease. Mol Cell Biochem. 2011;357(1-2): 171-9.

79 Grzelak A, Kruszewski M, Macierzyńska E, Piotrowski Ł, Pułaski Ł, Rychlik B, et al. The effects of superoxide dismutase knockout on the oxidative stress parameters and survival of mouse erythrocytes. Cell Mol Biol Letters. 2009;14(1):23-34.

80 Iuchi Y, Okada F, Onuma K, Onoda T, Asao $\mathrm{H}$, Kobayashi $\mathrm{M}$, et al. Elevated oxidative stress in erythrocytes due to a SOD1 deficiency causes anaemia and triggers autoantibody production. Biochem J. 2007;402(2):219-27.

81 Qadri SM, Bissinger R, Solh Z, Oldenborg PA. Eryptosis in health and disease: A paradigm shift towards understanding the (patho)physiological implications of programmed cell death of erythrocytes. Blood Rev. 2017;31(6): 349-361.

82 Di PietroN, Giardinelli A, Sirolli V, Riganti C, Di Tomo P, Gazzano E, et al. Nitric oxide synthetic pathway and cGMP levels are altered in red blood cells from end-stage renal disease patients. Mol Cell Biochem. 2016;417(1-2): 155-67.

83 Iuchi $\mathrm{Y}$, Okada F, Onuma K, Onoda T, Asao $\mathrm{H}$, Kobayashi $\mathrm{M}$, et al. Elevated oxidative stress in erythrocytes due to a SOD1 deficiency causes anaemia and triggers autoantibody production. Biochem J. 2007;402(2):219-27.

84 Sudnitsyna J, Skverchinskaya E, Dobrylko I, Nikitina E, Gambaryan S, Mindukshev I. Microvesicle formation induced by oxidative stress in human erythrocytes. Antioxidants. 2020;9(10):929.

85 Muravlyova LE, Molotov-Luchanskiy VB, Bakirova RY, Kolesnikova YA, Nurgaliyeva AS, Klyuyev DA. The modified proteins in erythrocytes and regulation of erythrocytes volume in patients with chronic kidney disease. Eur Rev Med Pharmacol Sci. 2015; 19(22):4270-4.

86 Freikman I, Ringel I, Fibach E. Oxidative stress-induced membrane shedding from RBCs is Ca flux-mediated and affects membrane lipid composition. J Membr Biol. 2011; 240(2):73-82.

87 Huber SM, Uhlemann AC, Gamper NL, Duranton C, Kremsner PG, Lang F. Plasmodium falciparum activates endogenous $\mathrm{Cl}(-)$ channels of human erythrocytes by membrane oxidation. EMBO J. 2002;21(1-2):22-30.

88 Myssina S, Lang PA, Kempe DS, Kaiser S, Huber SM, Wieder T, et al. Cl- channel blockers NPPB and niflumic acid blunt $\mathrm{Ca}(2+)$-induced erythrocyte 'apoptosis. Cell Physiol Biochem. 2004;14(4-6):241-8.
89 Antonelou MH, Kriebardis AG, Velentzas AD, Kokkalis AC, Georgakopoulou SC, Papassideri IS. Oxidative stress-associated shape transformation and membrane proteome remodeling in erythrocytes of end stage renal disease patients on hemodialysis. J Proteomics. 2011;74(11):2441-52.

90 Glogowska E, Gallagher PG. Disorders of erythrocyte volume homeostasis. Int J Lab Hematol. 2015;37 Suppl 1(0 1):85-91.

91 Remigante A, Morabito R, Marino A. Band 3 protein function and oxidative stress in erythrocytes. J Cell Physiol. 2021;236(9): 6225-34.

92 Saradhadevi V, Sakthivel R, Vedamoorthy S, Selvam R, Parinandi N. Alterations in band 3 protein and anion exchange in red blood cells of renal failure patients. Mol Cell Biochem. 2005;273(1-2):11-24.

93 Morabito R, Remigante A, Di Pietro ML, Giannetto A, La Spada G, Marino A. SO4 = uptake and catalase role in preconditioning after $\mathrm{H} 2 \mathrm{O} 2$-induced oxidative stress in human erythrocytes. Pflugers Arch. 2017;469(2): 235-50.

94 Morabito R, Falliti G, Geraci A, Spada GL, Marino A. Curcumin protects - $\mathrm{SH}$ groups and sulphate transport after oxidative damage in human erythrocytes. Cell Physiol Biochem. 2015;36(1):345-57.

95 Gao C, Ji S, Dong W, Qi Y, Song W, Cui D, et al. Indolic uremic solutes enhance procoagulant activity of red blood cells through phosphatidylserine exposure and microparticle release. Toxins. 2015;7(11):4390-403.

96 Firat U, Kaya S, Cim A, Büyükbayram H, Gökalp O, Dal MS, et al. Increased caspase-3 immunoreactivity of erythrocytes in STZ diabetic rats. Exp Diabetes Res. 2012;2012: 316384.

97 Mandal D, Moitra PK, Saha S, Basu J. Caspase 3 regulates phosphatidylserine externalization and phagocytosis of oxidatively stressed erythrocytes. FEBS Lett. 2002; 513(2-3):184-8.

98 Berg CP, Engels IH, Rothbart A, Lauber K, Renz A, Schlosser SF, et al. Human mature red blood cells express caspase- 3 and caspase- 8 , but are devoid of mitochondrial regulators of apoptosis. Cell Death Differ. 2001; 8(12):1197-206

99 Mandal D, Baudin-Creuza V, Bhattacharyya A, Pathak S, Delaunay J, Kundu M, et al. Caspase 3-mediated proteolysis of the N-terminal cytoplasmic domain of the human erythroid anion exchanger 1 (band 3). J Biol Chem. 2003;278(52):52551-8.

100 Miki Y, Tazawa T, Hirano K, Matsushima H, Kumamoto S, Hamasaki N, et al. Clearance of oxidized erythrocytes by macrophages: involvement of caspases in the generation of clearance signal at band 3 glycoprotein. Biochem Biophys Res Commun. 2007;363(1): $57-62$.
101 Polak-Jonkisz D, Purzyc L, Szcepańska M, Makulska I. Erythrocyte caspase-3 levels in children with chronic kidney disease. Clin Biochem. 2013;46(3):219-24.

102 Tellone E, Ficarra S, Russo A, Bellocco E, Barreca $\mathrm{D}$, Laganà $\mathrm{G}$, et al. Caffeine inhibits erythrocyte membrane derangement by antioxidant activity and by blocking caspase 3 activation. Biochimie. 2012;94(2):393-402.

103 Tozoni SS, Dias GF, Bohnen G, Grobe N, Pecoits-Filho R, Kotanko P, et al. Uremia and hypoxia independently induce eryptosis and erythrocyte redox imbalance. Cel Physiol Biochem. 2019;53:794-804.

104 Grygorczyk R, Orlov SN. Effects of hypoxia on erythrocyte membrane properties-implications for intravascular hemolysis and purinergic control of blood flow. Front Physiol. 2017;8:1110.

105 Chowdhury A, Dasgupta R. Effects of acute hypoxic exposure on oxygen affinity of human red blood cells. Appl Opt. 2017;56(3): $439-45$.

106 Tang F, Feng L, Li R, Wang W, Liu H, Yang Q, et al. Inhibition of suicidal erythrocyte death by chronic hypoxia. High Alt Med Biol. 2019;20(2):112-9.

107 Arias CF, Arias CF. How do red blood cells know when to die? R Soc Open Sci. 2017; 4(4): 160850.

108 Jean G, Piperno D, François B, Charra B. Sleep apnea incidence in maintenance hemodialysis patients: influence of dialysate buffer. Nephron. 1995;71(2):138-42.

109 Meyring-Wösten A, Zhang H, Ye X, Fuertinger DH, Chan L, Kappel F, et al. Intradialytic hypoxemia and clinical outcomes in patients on hemodialysis. Clin J Am Soc Nephrol. 2016;11(4):616-25.

110 Valentim-Coelho C, Vaz F, Antunes M, Neves S, Martins IL, Osório H, et al. Redoxoligomeric state of peroxiredoxin-2 and glyceraldehyde-3-phosphate dehydrogenase in obstructive sleep apnea red blood cells under positive airway pressure therapy. Antioxidants. 2020;9(12).

111 Lang E, Qadri SM, Lang F. Killing me softly: suicidal erythrocyte death. Int J Biochem Cell Biol. 2012;44(8):1236-43.

112 Dias GF, Tozoni SS, Bohnen G, Grobe N, Rodrigues SD, Meireles T, et al. Uremia and inadequate oxygen supply induce eryptosis and intracellular hypoxia in red blood cells. Cell Physiol Biochem. 2021;55(4):449-59.

113 Dounousi E, Papavasiliou E, Makedou A, Ioannou K, Katopodis KP, Tselepis A, et al. Oxidative stress is progressively enhanced with advancing stages of CKD. Am J Kidney Dis. 2006;48(5):752-60.

114 Mekki K, Taleb W, Bouzidi N, Kaddous A Bouchenak M. Effect of hemodialysis and peritoneal dialysis on redox status in chronic renal failure patients: a comparative study. Lipids Health Dis. 2010;9:93. 
115 Sommerburg O, Grune T, Hampl H, Riedel E, van Kuijk FJ, Ehrich JH, et al. Does longterm treatment of renal anaemia with recombinant erythropoietin influence oxidative stress in haemodialysed patients? Nephrol Dial Transplant. 1998;13(10):2583-7.

116 Jie KE, Verhaar MC, Cramer MJ, van der Putten K, Gaillard CA, Doevendans PA, et al. Erythropoietin and the cardiorenal syndrome: cellular mechanisms on the cardiorenal connectors. Am J Physiol Renal Physiol. 2006;291(5):F932-44.

117 Mircescu G, Căpuşă C, Stoian I, Mărăcine M, Muscurel C, Gârneată L, et al. Influence of epoietinum therapy on the oxidative stress in haemodialysis patients. Nephron Clin Pract. 2005;100(4):c126-32.

118 Myssina S, Huber SM, Birka C, Lang PA, Lang KS, Friedrich B, et al. Inhibition of erythrocyte cation channels by erythropoietin. J Am Soc Nephrol. 2003;14(11):2750-7.

119 Siems W, Carluccio F, Radenkovic S, Grune $\mathrm{T}$, Hampl H. Oxidative stress in renal anemia of hemodialysis patients is mitigated by epoetin treatment. Kidney Blood Press Res. 2005;28(5-6):295-301.

120 Föller M, Kasinathan RS, Koka S, Huber SM, Schuler B, Vogel J, et al. Enhanced susceptibility to suicidal death of erythrocytes from transgenic mice overexpressing erythropoietin. Am J Physiol Regul Integr Comp Physiol. 2007;293(3):R1127-34.

121 Mihov D, Vogel J, Gassmann M, Bogdanova A. Erythropoietin activates nitric oxide synthase in murine erythrocytes. Am J Physiol Cell Physiol. 2009;297(2):C378-88.

122 Chan D, Irish A, Croft KD, Dogra G. Effect of ascorbic acid supplementation on plasma isoprostanes in haemodialysis patients. Nephrol Dial Transplant. 2006;21(1):234-5 .

123 Jagadish S, Hemshekhar M, NaveenKumar SK, Sharath Kumar KS, Sundaram MS, Basappa, et al. Novel oxolane derivative DMTD mitigates high glucose-induced erythrocyte apoptosis by regulating oxidative stress. Toxicol Appl Pharmacol. 2017;334:167-79.

124 Sun Y, Liu G, Jiang Y, Wang H, Xiao H, Guan G. Erythropoietin protects erythrocytes against oxidative stress-induced eryptosis in vitro. Clin Lab. 2018;64(3):365-9.

125 Vota DM, Crisp RL, Nesse AB, Vittori DC. Oxidative stress due to aluminum exposure induces eryptosis which is prevented by erythropoietin. J Cell Biochem. 2012;113(5): 1581-9.

126 Vota DM, Maltaneri RE, Wenker SD, Nesse $\mathrm{AB}$, Vittori DC. Differential erythropoietin action upon cells induced to eryptosis by different agents. Cell Biochem Biophys. 2013; 65(2):145-57.

127 Ghashghaeinia M, Wesseling MC, Ramos E, Petkova-Kirova P, Waibel S, Lang E, et al. Trifluoperazine-induced suicidal erythrocyte death and S-nitrosylation inhibition, reversed by the nitric oxide donor sodium nitroprusside. Cell Physiol Biochem. 2017; 42(5):1985-98.
128 Nicolay JP, Liebig G, Niemoeller OM, Koka S, Ghashghaeinia M, Wieder T, et al. Inhibition of suicidal erythrocyte death by nitric oxide. Pflugers Arch. 2008;456(2):293-305.

129 Mahmud H, Qadri SM, Föller M, Lang F. Inhibition of suicidal erythrocyte death by vitamin C. Nutrition. 2010;26(6):671-6.

130 Shan F, Yang R, Ji T, Jiao F. Vitamin C inhibits aggravated eryptosis by hydrogen peroxide in glucose-6-phosphated dehydrogenase deficiency. Cell Physiol Biochem. 2016; 39(4):1453-62.

131 Qadri SM, Föller M, Lang F. Inhibition of suicidal erythrocyte death by resveratrol. Life Sci. 2009;85(1-2):33-8.

132 Farag MR, Alagawany M, Tufarelli V. In vitro antioxidant activities of resveratrol, cinnamaldehyde and their synergistic effect against cyadox-induced cytotoxicity in rabbit erythrocytes. Drug Chem Toxicol. 2017; 40(2):196-205.

133 Officioso A, Alzoubi K, Lang F, Manna C. Hydroxytyrosol inhibits phosphatidylserine exposure and suicidal death induced by mercury in human erythrocytes: possible involvement of the glutathione pathway. Food Chem Toxicol. 2016;89:47-53.

134 Qian EW, Ge DT, Kong SK. Salidroside protects human erythrocytes against hydrogen peroxide-induced apoptosis. J Nat Prod. 2012;75(4):531-7.

135 Mahmud H, Mauro D, Foller M, Lang F. Inhibitory effect of thymol on suicidal erythrocyte death. Cell Physiol Biochem. 2009; 24(5-6):407-14.

136 Fallatah O, Georges E. Apigenin-induced ABCC1-mediated efflux of glutathione from mature erythrocytes inhibits the proliferation of Plasmodium falciparum. Int J Antimicrob Agents. 2017;50(5):673-7.

137 Sun Y, Liu G, Li X, Shi Y, Guan G. L-Carnitine inhibits eryptosis induced by uremic serum and the related mechanisms. Ren Fail. 2015;37(6):1050-6.

138 Gatidis S, Meier A, Jilani K, Lang E, Zelenak C, Qadri SM, et al. Phlorhizin protects against erythrocyte cell membrane scrambling. J Agric Food Chem. 2011;59(15): 8524-30.

139 Shaik N, Zbidah M, Lang F. Inhibition of $\mathrm{Ca}(2+)$ entry and suicidal erythrocyte death by naringin. Cell Physiol Biochem. 2012; 30(3):678-86

$140 \mathrm{Al}$ Mamun Bhuyan A, Cao H, Lang F. Triggering of eryptosis, the suicidal erythrocyte death by mammalian target of rapamycin (mTOR) inhibitor temsirolimus. Cell Physiol Biochem. 2017;42(4):1575-91.

141 Liu J, Bhuyan AAM, Ma K, Zhang S, Cheng A, Lang F. Inhibition of suicidal erythrocyte death by pyrogallol. Mol Biol Rep. 2020; 47(7):5025-32.

142 Jemaà M, Fezai M, Lang F. Inhibition of suicidal erythrocyte death by reversine. Cell Physiol Biochem. 2017;41(6):2363-73.
143 Al Mamun Bhuyan A, Sahu I, Cao H, Lang F. Sonidegib, a novel inhibitor of suicidal erythrocyte death. Cell Physiol Biochem. 2018;47(4):1352-64.

144 Ghashghaeinia M, Koralkova P, Giustarini D, Mojzikova R, Fehrenbacher B, Dreischer $\mathrm{P}$, et al. The specific PKC- $\alpha$ inhibitor chelerythrine blunts costunolide-induced eryptosis. Apoptosis. 2020;25(9-10):674-85.

145 Qadri SM, Mahmud H, Föller M, Lang F. Inhibition of suicidal erythrocyte death by xanthohumol. J Agric Food Chem. 2009; 57(16):7591-5.

146 Zierle J, Bissinger R, Lang F. Inhibition by teriflunomide of erythrocyte cell membrane scrambling following energy depletion, oxidative stress and ionomycin. Cell Physiol Biochem. 2016;39(5):1877-90.

147 Al Mamun Bhuyan A, Bissinger R, Cao H, Lang F. Inhibition of erythrocyte cell membrane scrambling by ASP3026. Cell Physiol Biochem. 2017;43(2):507-17.

148 Lang KS, Lang PA, Bauer C, Duranton C, Wieder T, Huber SM, et al. Mechanisms of suicidal erythrocyte death. Cell Physiol Biochem. 2005;15(5):195-202.

149 Föller M, Huber SM, Lang F. Erythrocyte programmed cell death. IUBMB life. 2008 60(10):661-8.

150 Viskupicova J, Blaskovic D, Galiniak S, Soszyński M, Bartosz G, Horakova L, et al. Effect of high glucose concentrations on human erythrocytes in vitro. Redox Biol. 2015; 5:381-7.

151 Kumar R. Biochemical changes in erythrocyte membrane in type 2 diabetes mellitus. Indian J Med Sci. 2012;66(5-6):131-5.

152 Verma N, Liu M, Ly H, Loria A, Campbell KS, Bush H, et al. Diabetic microcirculatory disturbances and pathologic erythropoiesis are provoked by deposition of amyloidforming amylin in red blood cells and capillaries. Kidney Int. 2020;97(1):143-55.

153 Morabito R, Remigante A, Spinelli S, Vitale G, Trichilo V, Loddo S, et al. High glucose concentrations affect band 3 protein in human erythrocytes. Antioxidants. 2020;9(5).

154 Nicolay JP, Schneider J, Niemoeller OM, Artunc F, Portero-Otin M, Haik GJr, et al. Stimulation of suicidal erythrocyte death by methylglyoxal. Cell Physiol Biochem. 2006; 18(4-5):223-32.

155 Stapleton D, Mitchelhill KI, Gao G, Widmer J, Michell BJ, Teh T, et al. Mammalian AMPactivated protein kinase subfamily. J Biol Chem. 1996;271(2):611-4.

156 Cheung PC, Salt IP, Davies SP, Hardie DG, Carling D. Characterization of AMP-activated protein kinase gamma-subunit isoforms and their role in AMP binding. Biochem J. 2000;346(Pt 3):659-69.

157 Föller M, Sopjani M, Koka S, Gu S, Mahmud $\mathrm{H}$, Wang K, et al. Regulation of erythrocyte survival by AMP-activated protein kinase. FASEB J. 2009;23(4):1072-80. 
158 Foretz M, Hébrard S, Guihard S, Leclerc J, Do Cruzeiro M, Hamard G, et al. The AMPK $\gamma 1$ subunit plays an essential role in erythrocyte membrane elasticity, and its genetic inactivation induces splenomegaly and anemia. FASEB J. 2011;25(1):337-47.

159 Winder WW, Thomson DM. Cellular energy sensing and signaling by AMP-activated protein kinase. Cell Biochem Biophys. 2007; 47(3):332-47.

160 Peng Z, Luo R, Xie T, Zhang W, Liu H, Wang W, et al. Erythrocyte adenosine A2B receptor-mediated AMPK activation: a missing component counteracting CKD by promoting oxygen delivery. J Am Soc Nephrol. 2019;30(8):1413-24.

161 Wang S, Dale GL, Song P, Viollet B, Zou MH. AMPKalphal deletion shortens erythrocyte life span in mice: role of oxidative stress. J Biol Chem. 2010;285(26):19976-85.

162 Hardie DG. The AMP-activated protein kinase pathway: new players upstream and downstream. J Cell Sci. 2004;117(Pt 23): 5479-87.

163 Ladli M, Richard C, Aguilar LC, Ducamp S, Bondu S, Sujobert P, et al. Finely-tuned regulation of AMP-activated protein kinase is crucial for human adult erythropoiesis. Haematologica. 2019;104(5):907-18.

164 Hosseinzadeh Z, Honisch S, Schmid E, Jilani $\mathrm{K}$, Szteyn K, Bhavsar S, et al. The role of janus kinase 3 in the regulation of $\mathrm{Na}+\mathrm{K}+$ ATPase under energy depletion. Cell Physiol Biochem. 2015;36(2):727-40.

165 Zelenak C, Eberhard M, Jilani K, Qadri SM, Macek B, Lang F, et al. Protein kinase CK1a regulates erythrocyte survival. Cell Physiol Biochem. 2012;29(1-2):171-80.

166 Vanholder R, De SmetR, Glorieux G, Argilés A, Baurmeister U, Brunet P, et al. Review on uremic toxins: classification, concentration, and interindividual variability. Kidney Int. 2003;63(5):1934-43.

167 Sirich TL, Meyer TW, Gondouin B, Brunet P, Niwa T T. Protein-bound molecules: a large family with a bad character. Semin Nephrol. 2014;34(2):106-17.

168 Abed M, Artunc F, Alzoubi K, Honisch S, Baumann D, Föller M, et al. Suicidal erythrocyte death in end-stage renal disease. J Mol Med (Berl). 2014;92(8):871-9.

169 Sato Y, Mizuguchi T, Shigenaga S, Yoshikawa E, Chujo K, Minakuchi J, et al. Shortened red blood cell lifespan is related to the dose of erythropoiesis-stimulating agents requirement in patients on hemodialysis. Ther Apher Dial. 2012;16(6):522-8.

170 Ahmed MS, Abed M, Voelkl J, Lang F. Triggering of suicidal erythrocyte death by uremic toxin indoxyl sulfate. BMC Nephrol. 2013;14:244.

171 Voelkl J, Alzoubi K, Mamar AK, Ahmed MSE, Abed M, Lang F. Stimulation of Suicidal Erythrocyte Death by Increased Extracellular Phosphate Concentrations. Kidney Blood Press Res. 2013;38(1):42-51.
172 Ahmed MS, Langer H, Abed M, Voelkl J, Lang F. The uremic toxin acrolein promotes suicidal erythrocyte death. Kidney Blood Press Res. 2013;37(2-3):158-67.

173 Föller M, Sopjani M, Mahmud H, Lang F. Vanadate-induced suicidal erythrocyte death. Kidney Blood Press Res. 2008;31(2): 87-93.

174 Meyer TW, Hostetter TH. Uremic solutes from colon microbes. Kidney Int. 2012; 81(10):949-54.

$175 \mathrm{Wu}$ W, Bush KT, Nigam SK. Key Role for the Organic Anion Transporters, OAT1 and OAT3, in the in vivo Handling of Uremic Toxins and Solutes. Sci Rep. 2017;7(1): 4939.

176 Takada T, Yamamoto T, Matsuo H, Tan JK, Ooyama K, Sakiyama M M, et al. Identification of ABCG2 as an Exporter of Uremic Toxin Indoxyl Sulfate in Mice and as a Crucial Factor Influencing CKD Progression. Sci Rep. 2018;8(1):11147.

177 Barreto FC, Barreto DV, Liabeuf S, Meert N, Glorieux G G, Temmar M, et al. Serum indoxyl sulfate is associated with vascular disease and mortality in chronic kidney disease patients. Clin J Am Soc Nephrol. 2009;4(10): 1551-8.

178 Lin CJ, Liu HL, Pan CF, Chuang CK, Jayakumar T, Wang TJ, et al. Indoxyl sulfate predicts cardiovascular disease and renal function deterioration in advanced chronic kidney disease 2012;43(6):451-6. Arch Med Res. 2012;43(6):451-6.

179 Dou L, Jourde-Chiche N, Faure V, Cerini C, Berland Y, Dignat-George F, et al. The uremic solute indoxyl sulfate induces oxidative stress in endothelial cells. J Thromb Haemost. 2007;5(6):1302-8.

180 Deltombe O, Glorieux G, Marzouki S, Masereeuw R, Schneditz D, Eloot S. Selective Transport of Protein-Bound Uremic Toxins in Erythrocytes. Toxins. 2019;11(7).

181 Dias GF, Bonan NB, Steiner TM, Tozoni SS, Rodrigues S, Nakao LS, et al. Indoxyl Sulfate, a Uremic Toxin, Stimulates Reactive Oxygen Species Production and Erythrocyte Cell Death Supposedly by an Organic Anion Transporter 2 (OAT2) and NADPH Oxidase Activity-Dependent Pathways. Toxins. 2018;10(7).

182 Bush KT, Singh P, Nigam SK. Gut-derived uremic toxin handling in vivo requires OAT mediated tubular secretion in chronic kidney disease. JCI insight. 2020;5(7).

183 Kim SH, Yu MA, Ryu ES, Jang YH, Kang DH. Indoxyl sulfate-induced epithelial-tomesenchymal transition and apoptosis of renal tubular cells as novel mechanisms of progression of renal disease. Lab Invest. 2012; 92(4):488-98.

184 Gatidis S, Zelenak C, Fajol A, Lang E, Jilani $\mathrm{K}$, Michael D, et al. p38 MAPK activation and function following osmotic shock of erythrocytes. Cell Physiol Biochem. 2011; 28(6):1279-86.
185 Shantsila E, Montoro-García S, Gallego P, Lip GY. Circulating microparticles: challenges and perspectives of flow cytometric assessment. Thromb Haemost. 2014;111(6): 1009-14.

186 Erem S, Razzaque MS. Dietary phosphate toxicity: an emerging global health concern. Histochem Cell Biol. 2018;150(6):711-9.

187 Vervloet MG, Sezer S, Massy ZA, Johansson L, Cozzolino M, Fouque D. The role of phosphate in kidney disease. Nat Rev Nephrol. 2017;13(1):27-38.

188 Hosokawa S, Yoshida O. Serum vanadium levels in chronic hemodialysis patients. Nephron. 1993;64(3):388-94.

189 Benabe JE, Echegoyen LA, Pastrana B, Martínez-Maldonado M. Mechanism of inhibition of glycolysis by vanadate. J Biol Chem. 1987;262(20):9555-60.

190 Kim YL, Kim H, Kwon YE, Ryu DR, Lee MJ, Park KS, et al. Association between Vitamin D Deficiency and Anemia in Patients with End-Stage Renal Disease: A Cross-Sectional Study. Yonsei Med J. 2016;57(5):1159-64.

191 Sim JJ, Lac PT, Liu IL, Meguerditchian SO, Kumar VA, Kujubu DA, et al. Vitamin D deficiency and anemia: a cross-sectional study. Ann Hematol. 2010;89(5):447-52.

192 Patel NM, Orlando GutiérrezM, Andress DL, Coyne DW, Levin A, Wolf M. Vitamin D deficiency and anemia in early chronic kidney disease. Kidney Int. 2010;77(8):71520.

193 Kempe DS, Ackermann TF, Fischer SS, Koka S, Boini KM, Mahmud H, et al. Accelerated suicidal erythrocyte death in Klothodeficient mice. Pflugers Arch. 2009;458(3): 503-12.

194 Vadakke MadathilS, Coe LM, Casu C, Sitara D. Klotho deficiency disrupts hematopoietic stem cell development and erythropoiesis. Am J Pathol. 2014;184(3):827-41.

195 Lang E, Jilani K, Bissinger R, Rexhepaj R, Zelenak C, Lupescu A, et al. Vitamin D-Rich Diet in Mice Modulates Erythrocyte Survival. Kidney Blood Press Res. 2015;40(4):40312.

196 White JH. Regulation of intracrine production of 1,25-dihydroxyvitamin D and its role in innate immune defense against infection. Arch Biochem Biophys. 2012;523(1):58-63.

197 Klarl BA, Lang PA, Kempe DS, Niemoeller OM, Akel A, Sobiesiak M, et al. Protein kinase $\mathrm{C}$ mediates erythrocyte "programmed cell death" following glucose depletion. Am J Physiol Cell Physiol. 2006;290(1):C244-53.

198 Kempe DS, Lang PA, Duranton C, Akel A, Lang KS, Huber SM, et al. Enhanced programmed cell death of iron-deficient erythrocytes. FASEB J. 2006;20(2):368-70.

199 Schaefer RM, Schaefer L. Hypochromic red blood cells and reticulocytes. Kidney international Supplement. Kidney Int Suppl. 1999;69:S44-8. 10084285. 
200 Dekkers DW, Comfurius P, Bevers EM, Zwaal RF. Comparison between Ca2+-induced scrambling of various fluorescently labelled lipid analogues in red blood cells. Biochem J. 2002;362(Pt 3):741-7. 11879203.

201 Lang PA, Kaiser S, Myssina S, Wieder T, Lang F, Huber SM. Role of Ca2+-activated $\mathrm{K}+$ channels in human erythrocyte apoptosis. Am J Physiol Cell Physiol. 2003;285(6): C1553-60.

202 Nagababu E, Gulyani S, Earley CJ, Cutler RG, Mattson MP, Rifkind JM. Iron-deficiency anaemia enhances red blood cell oxidative stress. Free Radic Res. 2008;42(9):824-9.

203 du Plooy JN, Bester J, Pretorius E. Eryptosis in haemochromatosis: implications for rheology. Clin Hemorheol Microcirc. 2018; 69(4):457-69.
204 Alfhili MA, Nkany MB, Weidner DA, Lee $\mathrm{MH}$. Stimulation of eryptosis by broad-spectrum insect repellent N,N-Diethyl-3-methylbenzamide (DEET). Toxicol Appl Pharmacol. 2019;370:36-43.

205 Fink M, Bhuyan AAM, Nürnberg B, Faggio C, Lang F. Triggering of eryptosis, the suicidal erythrocyte death, by phenoxodiol. Naunyn Schmiedebergs Arch Pharmacol. 2019;392(10):1311-8.

206 Bigdelou P, Farnoud AM. Induction of eryptosis in red blood cells using a calcium ionophore. J Vis Exp;2020;(155):60659.

207 Ghashghaeinia M, Mrowietz U, Dreischer P, Köberle M. Association between nuclear factor of kappa B (NFkB) deficiency and induction of eryptosis in mouse erythrocytes. Apoptosis. 2021;26(1-2):4-6.

208 Naveed A, Jilani K, Siddique AB, Akbar M Riaz M, Mushtaq Z, et al. Induction of erythrocyte shrinkage by omeprazole. Dose-response. 2020;18(3):1559325820946941.
209 Ghashghaeinia M, Cluitmans JC, Akel A, Dreischer P, Toulany M, Köberle M, et al. The impact of erythrocyte age on eryptosis. Br J Haematol. 2012;157(5):606-14.

210 Cheloni G, Slaveykova VI. Optimization of the C11-BODIPY(581/591) dye for the determination of lipid oxidation in Chlamydomonas reinhardtii by flow cytometry. $\mathrm{Cy}$ tometry A. 2013;83(10):952-61.

211 Yeung KW, Lau PM, Tsang HL, Ho HP, Kwan YW, Kong SK. Extracellular histones induced eryptotic death in human erythrocytes. Cell Physiol Biochem. 2019;53(1): 229-41.

212 Föller M, Feil S, Ghoreschi K, Koka S, Gerling $\mathrm{A}$, Thunemann $\mathrm{M}$, et al. Anemia and splenomegaly in cGKI-deficient mice. Proc Natl Acad Sci U S A. 2008;105(18):6771-6. 